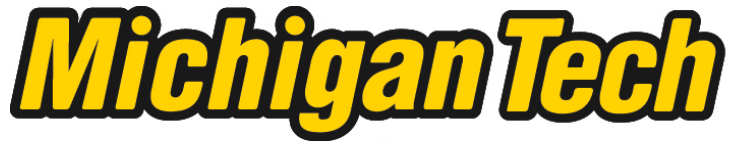 \\ Michigan Technological University Create the Future Digital Commons @ Michigan Tech
}

Dissertations, Master's Theses and Master's Reports - Open

Dissertations, Master's Theses and Master's

Reports

2015

\section{ENGAGING METIS: EXPLORING AN AFRICAN WOMAN'S NEGOTIATION OF CHANGE}

Ruby Pappoe

Michigan Technological University

Follow this and additional works at: https://digitalcommons.mtu.edu/etds

Part of the African Studies Commons, and the Women's Studies Commons Copyright 2015 Ruby Pappoe

\section{Recommended Citation}

Pappoe, Ruby, "ENGAGING METIS: EXPLORING AN AFRICAN WOMAN'S NEGOTIATION OF CHANGE", Master's Thesis, Michigan Technological University, 2015.

https://doi.org/10.37099/mtu.dc.etds/957

Follow this and additional works at: https://digitalcommons.mtu.edu/etds

Part of the African Studies Commons, and the Women's Studies Commons 


\title{
ENGAGING METIS: EXPLORING AN AFRICAN WOMAN'S NEGOTIATION OF CHANGE
}

\author{
By
}

Ruby Pappoe

\begin{abstract}
A THESIS
Submitted in partial fulfillment of the requirements for the degree of MASTER OF SCIENCE

In Rhetoric and Technical Communication

MICHIGAN TECHNOLOGICAL UNIVERSITY

2015
\end{abstract}

(C) 2015 Ruby Pappoe 

This thesis has been approved in partial fulfillment of the requirements for the Degree of MASTER OF SCIENCE in Rhetoric and Technical Communication.

Department of Humanities

Thesis Advisor: Dr. Ann Brady

Committee Member: Dr. Ramon Fonkoue

Committee Member: Dr. Patricia Sotirin

Committee Member: Dr. Kari Henquinet

Department Chair: Dr. Ronald Strickland 

To my mother and my partner, Alfred 



\section{Table of Content}

Acknowledgements ........................................................................................................................9

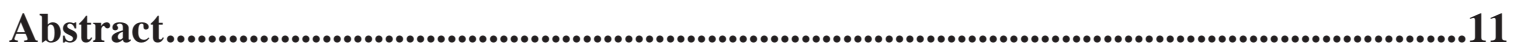

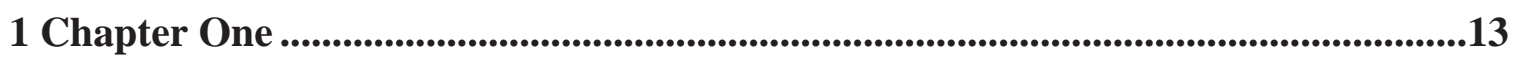

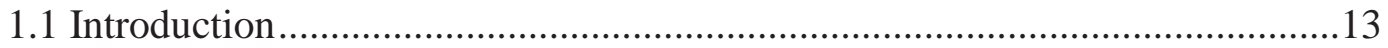

1.2 African Women's Activism: From the 1940s to the Late 1980s .....................15

1.2.1 Women's Participation in Armed Struggles .................................................20

1.3 African Women's Activism: From the 1990s to Present ...................................24

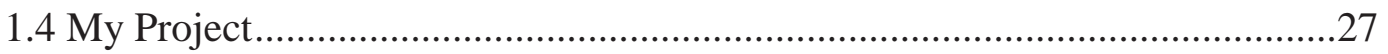

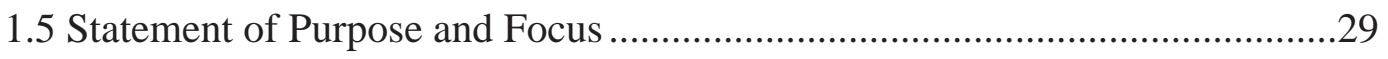

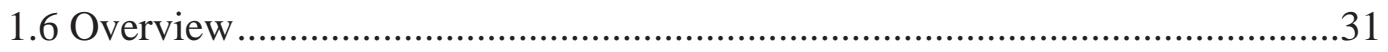

2 Chapter Two: Literature Review ....................................................................33

2.1 Women in Political Activism........................................................................33

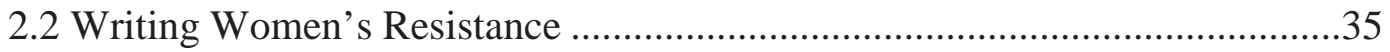

2.3 A Look at Metis in African Women's Engagement and Resistance ................40

3 Chapter Three: Methodology and Method............................................................................43

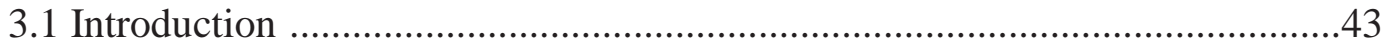

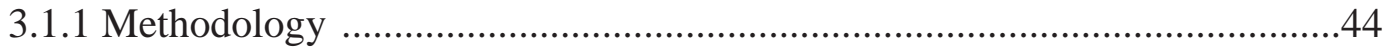

3.1.2 Exploration of Metis in Women's Activism................................................4

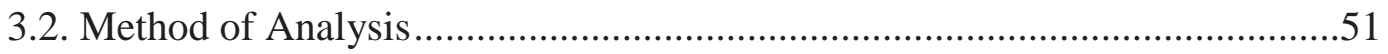

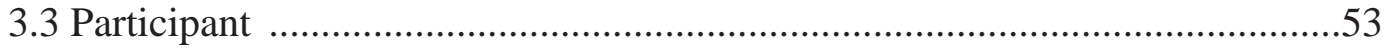

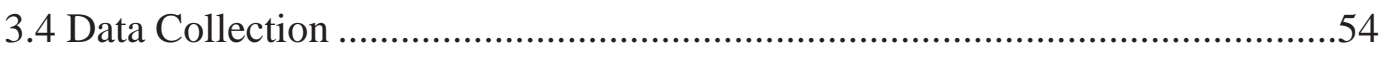

4 Chapter Four: Analysis .................................................................................................................57

4.1 Ghana: A Brief Background ...................................................................57

4.2 The Missing Baby Case: A Chronological Summary .....................................58

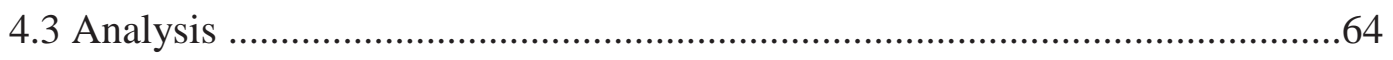

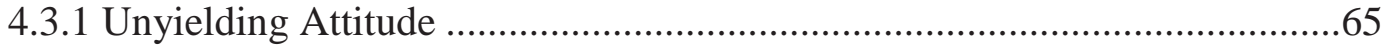

4.3.1.1 Suwaiba and Medical Authorities ...........................................................66

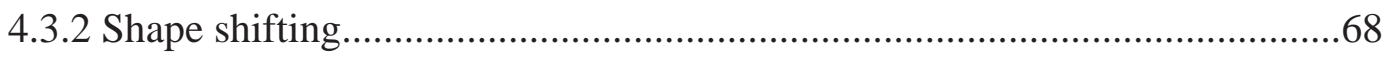

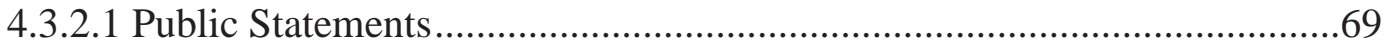




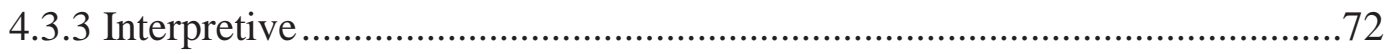

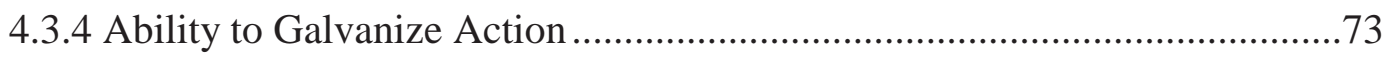

4.3.4.1 Responses from Political Figures...................................................... 74

4.3.4.2 Responses from the Public ................................................................. 75

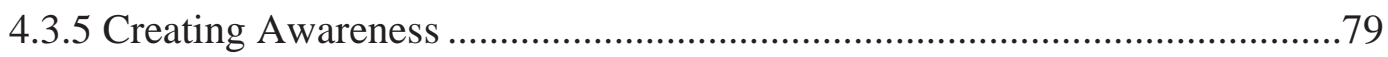

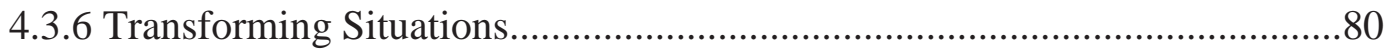

5 Chapter Five: Conclusion................................................................................................................83

5.1 Extending the Boundaries of Women's Activism .......................................8 83

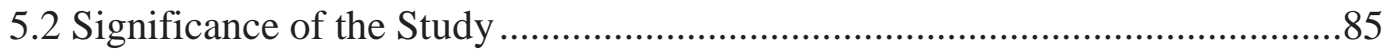

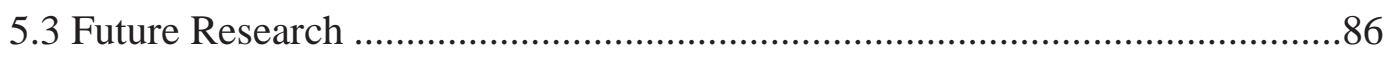

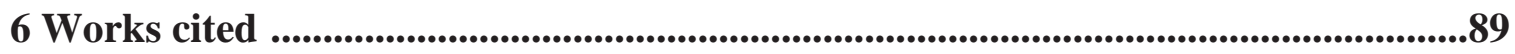

7 Appendix A

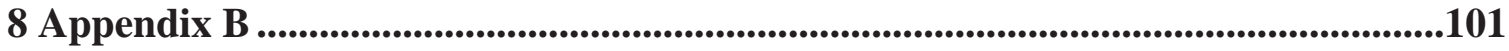




\section{Acknowledgements}

I would first like to thank the Almighty God for His graciousness and mercies. Without Him, I would not have been able to come this far, much less to even produce this work. I am very grateful to the Lord, He has been faithful.

I cannot thank my chair, Dr. Ann Brady, enough for her tremendous help. Her supervision was immeasurable. Her feedback and advice pushed me to come out successful with this work. When situations were tough, she enlightened my spirit with her words of encouragement. The promptness with which she assisted my research, in spite of her busy schedule, is also well appreciated.

I equally extend my gratitude to my committee members; Dr. Ramon Fonkoue, Dr. Patricia Sotirin, and Dr. Kari Henquinet, whose invaluable contributions successfully shaped this research. 


\section{Abstract}

African women's emerging visibility as social and political actors has received a lot of attention in the past two decades. Scholars have explored women's political movements and sociocultural activism from various perspectives to expose their contributions to social change. Although this scholarship has expanded to incorporate multiple voices as well as expose the contemporary strategies of resistance women engage in to overcome difficult challenges, there seems to be little research on ordinary women as they also confront their daily challenges in hope of improving their situations. This research takes up this gap by exploring a Ghanaian woman's resistance in the face of medical adversity and the outcomes that emerged. I employ the concept of metis, taking definitions from scholars such as Flynn et al., Detienne and Vernant, Dolmage, and Hawhee, to examine how the woman negotiated her situation to bring it to the attention of health authorities and the general public. I use rhetorical analysis to interpret, analyze, and evaluate the rhetorical actions that took place in response to the issue. Through this research, it becomes evident that metis plays an important role in allowing us to better understand the ways women, especially the marginalized, resist oppression. The study also broadens our knowledge of African women's strategies of resistance to include metistic strategies that the vulnerable employs to effectively negotiate adverse circumstances. 


\section{Chapter one}

\subsection{Introduction}

In the last two decades, scholars have taken a keen interest in exploring African women's activities as agents of social and political change. They have examined the ways in which African women have contributed to social change politically (Tripp et al.; Tripp 3; Hassim 2; Britton), culturally (Abu-Lughod; Hodgson; Mahmood), and economically (Clark; Harley). As this scholarship broadens to examine the global, political, and sociocultural processes that shape women's circumstances, particularly those of a minority status (Mohanty; de Hernandez), there is the need to further explore how minority women respond to their challenging conditions. Though researchers have recently paid attention to the lives of individual women in order to expose how they express resistance against difficult sociocultural challenges (de Hernandez; Braun), not much attention has been given to the resistance of ordinary women and the degrees of success they achieve.

This thesis explores one woman's resistance in the context of a situational exigency involving the disappearance of her baby's body. This incident took place in February 2014 at the Komfo Anokye Teaching Hospital (KATH) in Kumasi, Ghana, the country's second biggest hospital. I employ the theory of metis to analyze the woman's response to the issue, to not only expose the contemporary challenges that face many ordinary people in Africa today, but also to illustrate how they negotiate these challenges. I take a rhetorical analysis approach to look at the interactions that took place among the woman, medical authorities, and the general public in response to the case and the outcomes that emerged. This work 
contributes to scholarship on African women's activism. In what follows, I present a historical context of women's activism in Africa. 


\subsection{African Women's Activism: From the 1940s to the}

\section{Late 1980s}

The emergence of women's mobilization in Africa can be traced to the anticolonial movements. During this era, women publicly got involved in activities meant to promote the attainment of national freedom for their various countries. According to Tripp et al., this served as one of the few opportunities for women to participate in the public sphere (32). By the 1950s, many African countries had become weary of the pressures that they suffered from the presence of Western colonizers on their lands. Thus, they began to forcefully resist colonial rule in a variety of ways. Women traders for instance were dissatisfied with the economic turmoil that developed at the time as a result of colonialists' interference and in response to this situation, they formed civil society groups, established trade unions, and joined nationalist parties to fight for national independence (32). This participation in anticolonial resistance later influenced future mobilizations of women across the continent. The following paragraphs discuss the ways in which women in Africa have been involved in activism, starting from engagements in anticolonial resistances through to the development of autonomous women's movements, to contemporary activities.

A major motivation for women's mobilization during the colonial era was the oppression they endured from colonial authorities. In Women Writing Africa: The Southern Region, Daymond et al. recount some of the collective activities of women against colonial laws that infringed on their freedom. They enumerate how a group of women in central Namibia 
known as Herero women, came together to "protest against the threat of forced vaginal examinations of black women by the colonial authorities" (219). This law had been passed as part of a periodic compulsory examinations introduced by the colonial administration of South West Africa in 1939. The examinations subjected all unmarried black women in urban areas to be tested for venereal disease by foreign doctors. Daymond et al. added that at the time, "the administration was concerned with controlling the movements of women in order to extract labor and taxes from them," and this legislation seemed "to provide a way of regulating women economically and sexually" (219). Recognizing the oppressive situation they had been subjected to, eight women from the town of Keetmanshoop in Namibia, each representing her area of residence, wrote a collective letter to the colonial administration demanding that the law be repealed. In the letter, they spoke against the imposition placed on their bodies by the law and they expressed the negative experiences some of them had suffered from similar medical examinations (220). So forceful was the letter written that it soon provoked a halt in the examinations in some areas of the town. Many more women continued to protest and by the end of 1949, the law was repealed (220). Besides this group, another group known as the Herero Women, also came together to fight against the examinations, which they considered an invasion of their bodies and an assault on their cultural identity (221-224).

Another reason for the development of women's collectives and organizations was the economic struggles that prevailed as a result of colonial interference on trade. By the 1940s, most colonial administrations in Africa had taken control over the trading activities of the natives. They introduced taxes, increased market prices, implemented laws that regulated farming techniques, and took control over external trading activities (Tripp et al. 30). These 
processes affected women the most since many of them were agriculturalists and marketers. In response to the economic hardships, market women in countries such as Cameroon, Sierra Leone, and Nigeria, mobilized in the 1940s to protest against issues such as rising taxes and increased cost of agricultural produce. Thus, many organizations and associations were established to address these concerns. Notable among these were the Association of Cameroonian Women (ACW), Lagos Market Women's Association (LMWA), and Sierra Leone Women's Movement (WLWM) (Tripp et al. 40-43). These organizations protested in various ways to show their disapproval of the colonial administration and their demand of control over their marketing activities.

The LMWA for instance, was formed by a fish trader and head of market women to stage a protest against the colonial administration in Nigeria for imposing market taxes, price controls, and poor trading conditions on market women. Similarly, the Abeokuta Women's Union (AWU) in Nigeria "succeeded in getting female taxation suspended" (Tripp et al. 41). In addition, the Kom women in Cameroon, numbering about seven thousand, came together in the late 1950s to "ridicule and shame" British colonial officials for rising taxes among other issues (30). This protest usually involved women dressing like soldiers in torn trousers in order to express their dissatisfaction.

Even though it was not until the mid-1980s did struggles pertaining to women's rights flourish, some women groups actually became concerned with gender-specific issues as early as the 1940s. Gender-specific concerns emerged when women became aware of their low status in society and the underrepresentation of females in governance. For instance, in 1944, a group of women in Lagos, Nigeria realized that women were underrepresented 
in governance though a large number of women owned homes and paid taxes. The groups also identified gender inequality in education in that only boys had access to government scholarships. These gender-specific problems inspired Lady Oyinkan Morenike Abayomi, the leader of the group, to form the Women's Party in 1944. The party campaigned for women's rights, addressing issues such as "increased opportunities for girls' education," "literacy for adult women," and "more employment of women in the civil service." The party also campaigned for political offices for women and they "succeeded in getting women unto the Lagos Town Council" (Tripp et al. 43).

In some cases, women's participation was evident through the responsibilities they performed within the political parties they had joined. Here, women's needs were framed as part of the parties' ideologies. The $31^{\text {st }}$ December Women's Movement (31DWM), formed in 1982 in Ghana, is an example of this. The organization worked as part of the Provisional National Defense Council (PNDC) to specifically attend to the needs of women. Mostly made up of market women, the group helped to bring issues affecting women and minority groups to the attention of the party.

Furthermore, the desire to attain unity across ethnic and religious lines encouraged the formation of movements made up of women with various backgrounds and orientations to address issues facing women. Over the years, unity among women has been a major theme in African women's movements, particularly given the diverse ethnic and religious (mainly Christian and Muslim) backgrounds on the continent. In Sierra Leone, a women's organization aimed at providing a common national identity for women was established in 1951. The Sierra Leone's Women's Movement (WLWM) brought together nurses, market 
women, and business women to work towards issues such as social welfare, economy, improvement of women's status, and girls' education (Tripp et al. 43).

It is important to mention here that women activists faced many setbacks during the colonial regime, but they still continued to work towards productive social change. For instance, women's activities were suppressed by the colonial administration of their respective countries and this took a toll on the extent to which they formed associations and accomplished their goals (Tripp et al. 32). In an article that describes how colonialism weakened Igbo women's traditional autonomy and power, Van Allen argues that "the actions of administrators weakened and in some cases destroyed women's bases of strength" (165). This suppression manifested through the banning of women's consultative meetings and other functions by the British officials who colonized Nigeria (165). In addition, women's organizations that worked with political parties usually had their needs sidelined or ignored altogether. In spite of the limitations, successes such as, openness for female participation in politics, were achieved. For example Mabel Dove of Sierra Leone, the first woman in West Africa to be elected to the legislature, was appointed in 1954 (Tripp et al. 43). 


\subsubsection{Women's Participation in Armed Struggles}

In the 1950s when the fight for national freedom from colonialism was intensified in many African countries, women became involved in the wars, riots, demonstrations, party formations, and rallies that were staged. Notable among these activities are the armed struggles or liberation wars in which women played key roles. Though "their own specific gender-based goals were either subsumed or ignored within the more general nationalist movement," women still participated because they regarded the movement as essential to their own emancipation (Tripp et al. 36-37).

The most notable of women's participation in armed struggles was the involvement of Algerian women in Algerian's war of independence from the French colonizers. The Battle of Algiers, as this war is commonly referred to, took place between 1954 and 1962. This battle was motivated by upheavals in Algeria during the French colonial regime. Highlighting the efforts of women in the battle and its resultant impact on their identity, Fanon argues that women's presence in the war became "the hallmark of a national revolution's potential to liberate women" (Fanon 896). They acted as combatants, spies, fundraisers, nurses, and cooks as they actively advanced the attainment of freedom for their country. Some of them also played the role of educators who enlightened peasant women and other members about the goals of the movement (Turshen 890-891). The extent to which women participated in the war won them the right to education and entry into professions after independence.

Elsewhere, women played key roles in the success of their political parties. They organized rallies, attracted supporters, and were backbones to the successes of the movements. 
Notwithstanding the major roles played, women in the independence movements did little concerning women's rights. This is because their participation was strictly focused on furthering the elimination of colonialism. Besides, as mentioned earlier, nationalist leaders paid little attention to the challenges of women. By contrast, in places such as GuineaBissau and Mozambique, "women's liberation was considered integral to the liberation of the countries from colonial rule" and as such, was incorporated into the issues addressed by the movements (Tripp et al. 38).

Illustrating the effects of the participation of women in the armed struggles in Mozambique, Arnfred observes that women's engagement during this period enabled them to develop new self-awareness and abilities beyond the domestic activities they were subjected to. She argues, "some women developed a new concept of themselves as women: new aspirations, new goals. A new female identity was emerging." She continues by asserting that there was a surge of new gender equality as men and women worked together on equal terms during the liberation struggles (5-6). This change in gender relations was mostly evident in countries where women's emancipation was part of the fight for independence (Tripp et al. 38). Arnfred also identifies the development of new structures such as nationalist organizations, as giving added impetus to women's changing status in Mozambique:

New also was the structure of authority within which these tasks were carried out. In their normal daily lives, women are subordinated to patriarchal family authority, whether it be of a father, an uncle, a husband or a brother. Their lives are circumscribed and their gender role is defined by their position in the family. During the war, however, the family was not the ultimate source of authority. On the contrary. If there were conflicts between women and the male members of their families, if their husbands would not permit them to be absent to carry out their tasks of mobilisation or transport, women could call in Frelimo. A new authority 
was at work, an authority which, when necessary and for the time being, supported women against men (5-6).

Obviously, the participation of women in this era was limited to nationalist activism for self-governance without any activities geared towards addressing the needs of women. Nevertheless, women were exposed to formal political participation and enjoyed a considerable amount of freedom from patriarchal domination. This freedom, however, did not materialize into the emancipation of all women as expected. After independence, the political leaders reneged on the promises they made to the women, forcing many of them to return to domestic services. One Algerian woman veteran testifies thus, "we were all equal in the war-it was afterward that our citizenship was taken away from us" (Turshen 297).

Around the mid-80s when many countries had attained independence, women's involvement in public affairs gradually decreased. This was due to the fear of comprising the loyalty they had to the political parties they had become affiliated to since the fight for independence. Tripp et al. record that women who had joined the parties during the armed struggles felt strongly attached to their ideologies and thus, were hesitant to challenge their decisions. According to Staudt, because they were "incorporated under the wing of the party, they had limited capability to bargain and thus few benefits to extract (77). This enabled male leaders to coopt women's organizations and influence them to focus on narrow issues and personal gains (Tripp et al. 49). In addition, there was not much multiparty democracy in the 1980 s compared to later years. In light of these situations, there was not much activities by women during this period. 
In the other hand, women activists in other parts of the globe were staging massive campaigns on women's rights. The changes that some of these campaigns effected influenced the international landscape, particularly regarding the social activities of women in other places. In the West, activists campaigned for improved healthcare (1970s), equal rights (1972), and elective offices (1980s) for women. In the United States, for instance, the Women's Health Movement inspired changes such as abortion rights for women and improved maternity care and treatment of women patients (Schneir 361). American women also brought attention to female participation in politics. Activists, such as Bella Abzug, were influential in struggling for women to gain access to elected offices. Schneir documents that by 1993, there was a sudden jump in the number of women in Congressfrom 6 percent to nearly 10 percent" (394).

These changes inspired the establishment of new women's movements in Africa that were forceful in publicly broaching issues pertaining to women and development. The new women's movement emerged between the late 1980s and early 1990s, and were autonomous in nature. That is, they formed their own organizations, elected their own leaders, and advanced their own goals independent of any political parties. This enabled them to focus on the needs of women that have largely been neglected by the state. Access to new resources and funding, such as international aid, and the presence of a multiparty system, also contributed to the rise of these independent movements (Tripp et al. 62). With this new operation body, women gained the impetus to become more visible in influencing policy and social change. 


\subsection{From the 1990s to the Present}

In African Women's Movements: Changing Political Landscapes, Tripp et al. trace the proliferation of African women's autonomous activism to the 1990s. By this time, many of the political parties that women were affiliated to had begun to withdraw their restrictions on autonomous associations (56). In addition, the challenges of nation building that accompanied the postcolonial regime became a motivation for women to extricate themselves from the ruling parties to enable them tackle without constraints, the developmental issues that were affecting women's lives. Also, the emergence of multiparty democracy in Africa during the 1990s gave women the freedom to take their own actions. They established regional networks, participated in international conferences, and partnered with international bodies in the fight for women's rights.

The representation and role of women in the public sphere was a major preoccupation for the women's movements. They believed that the political participation of women was necessary to ensure that women were represented in the decision-making processes of their countries. With this goal, they developed various strategies to resist male dominance and push for gender equality in governance. These strategies included the internal and regional mobilization of women, participation in international conferences, and the creation of networks and organizations. These functioned as platforms to share information, reinforce women's roles in the transformation of their societies, and determine strategies of operation. For instance, Tripp et al. assert that "the majority of "electoral quotas for women... along with efforts for leadership and promotion of greater political participation 
by women," were inspired by the 1995 UN Beijing conference in which African women participated (67).

By the late nineties, women's visibility in politics had significantly increased. In South Africa, the percentage of women in national office, which was 2.4 percent before the 1994 elections, increased to 29.8 by 1999 (Britton 1). The presence of women in government ministries and structures gave them the opportunity to put pressure on the government to attend to the needs of women.

While many of these changes have been politically driven (Hassim 2; Tripp; Britton; Goetz; Tripp et al.), there have been instances where women have attended to issues concerning harmful cultural practices (Tripp 3; Hodgson; Liz Creel et al.) economic empowerment (Kim et al.), and violence against women (Dunkle). In the case of Ghana, a coalition of women's groups known as Sister's Keepers came together in 1999 and 2000 to demonstrate against a situation they understood as violence against women. For a period of four years, 1997 to 2001, about thirty women were murdered by a serial killer in Accra. Throughout the period, the ruling government, the National Democratic Congress (NDC), failed to respond to this crisis and this angered women. Thus, the group decided to take matters into their hands. They marched to the president's castle wailing and chanting dirges. This action however, did not move the government who continued to ignore the women. As a solution to their problem, the group influenced the public during the national elections to vote for a different party that will take measures to protect women (Viterna and Fallon 1-2).

Women have also worked with transnational networks to address issues such as gendered violence. Activists in Africa have joined forces in many ways to ensure that violence 
against women is treated as a priority. They have participated in international forums, such as the UN's Commission on the Status of Women (CSW) and the United Nations Populations Fund (UNFPA), to develop strategies to eliminate violence against women globally (Weldon 60; UNFPA.org). An outcome of such participation has been the involvement of African women in the 16 days of Activism campaign meant to sensitize people about gendered violence and the need for it to be eschewed. Furthermore, in Nigeria and South Africa, grassroots efforts have ensured the arrest and punishment of rapists and the elimination of Female Genital Cutting (FGC) (Hassim 2; Onyejekwe)

Over the years, women have formed Non-Governmental Organizations (NGO) coalitions, regional advocacy networks, and transnational alliances to advance women both politically and socially. The South African Women's Charter in 1994, the Uganda Women's Network in 1996, and the Ghanaian Women's Organizations in 2004, are among such NGO coalitions that work for the betterment of women. Some individual activists have also worked towards social change. A notable example is the late Wangari Maathai of Kenya who founded the Green Belt Movement in 1977 to advocate for better sustainability of the environment. Working with rural women, she helped them to secure access to resources such as clean drinking water (Usman 3).

The historical sketch above provides the social and political contexts within which African women's activism has developed. Today, the efforts of African women towards social change have been performed in various ways beyond the group and organizational levels. For instance, Ellen Johnson Sirleaf of Liberia and Ngozi Okonjo-Iweala of Nigeria are 
using their political offices to make an impact in their societies. Chimamanda Adichie is also using her literary voice to reclaim the dignity and efforts of women on the continent.

\subsection{My Project}

Despite the extensiveness of research on the involvement of women in activism, little attention has been given to grassroots women who engage in resistance not for political reasons, but as a response to the daily challenges that stem from contemporary social, cultural, and economic conditions that adversely impact their lives. Thus, how ordinary women faced with difficult challenges negotiate their situations, and the impact they produce in their lives and societies, have scarcely been theoretically studied. By ordinary women, I refer to the poor average woman, who is of a low social, economic, or class status. With regard to the subject of this study, Suwaiba, she is Muslim, uneducated, and poor; an ideal representation of the women I refer to as ordinary. In contrast, many of the activists in the studies above are not ordinary women. Usually these women are welleducated political leaders, leaders of women's groups, or academics. How then do women who do not have the advantage of such statuses approach situations that are beyond their control?

The contributors of Women Writing Resistance, in introducing their collection of writings depicting women's resistance, observe that, "women across the continent are working with grit, determination, and imagination to improve their own material conditions" (de Hernandez 3). The burgeoning of grassroots women responding to various crises has also been affirmed by Hassim (“Terms of engagement” 18). However, a critical examination of their engagements and effectiveness is scanty. When there is any mention of such activism, 
it is usually to only highlight their efforts. A good example of such is Rabi'atu Abubakar Mashi of Nigeria whose work as a female truck-driver with the Dangote Cement Company does not only defy gender stereotypes, but illustrates an ongoing perseverance to eke out a living for her family (Usman 7). Rabi'atu's resilience is clear. This case, among others, points to the fact that some women are actively taking control of their experiences to make their lives meaningful.

With many such women seeking to transform their lives instead of remaining in a state of victimization, there is the need to explore their engagements, particularly given the exercise of agency involved. This work's preoccupation with resistance as enacted by ordinary women is necessary for two main reasons. First, to contribute towards women's activism by looking at how the African subaltern, considered weak and voiceless, develop the capacity to become agents of change either for personal gains or for the benefit of their societies. Second, to expose the experiences of such women and the conditions that they are forced to contend with in today's society. This research will illuminate fresh perspectives on the significance and forms of women's struggles. My impulse to focus on the efforts of the common people arises from the belief that small struggles are critical to larger processes of change due to the awareness that is created in the process. As Mohanty argues, rather than just waiting for a revolution, we have to be attentive also to the small struggles and their potent effects (4). 


\subsection{Statement of Purpose and Focus}

The focus of my study is to analyze Suwaiba's strategies of resistance in response to the inability of medical staff to account for the body of her baby. My analysis examines how she negotiated the situation with authorities, moving them to pay attention to the issue as well as to the injurious conditions of maternal healthcare at the institution. I employ the concept of metis to examine the various actions and choices that Suwaiba utilized and the outcomes that emerged from them. Metis entails the use of various skills including resourcefulness, contextualized intelligence, and shape shifting, to realize engagement and create circumstances where opportunities can be seized (Flynn et al. 8-11). In line with this understanding of the concept, I look at Suwaiba's persistence, situational responses, ability to assume different identities, among other actions, that she used to engage the authorities and the forces she encountered. Questions to probe the analysis are:

- How did Suwaiba respond to her situation? i.e. What kinds of rhetorical actions did she take?

- What metistic strategies did Suwaiba display and what are their significance?

- To what extent was Suwaiba's resistance successful?

- How does the concept of metis advance our understanding of African women's resistance?

To answer these questions, I will take a rhetorical analysis approach. I use this method for these reasons: to examine my participant's actions of resistance and evaluate how productive she was. I apply Selzer's definition of rhetorical analysis to develop an 
analytical framework that looks at how the elements—-subject, audience, and, context — work in the case to achieve a particular effect. In this light, I look at how Suwaiba's resilient actions persuaded her audience, how the audience responded to her, and the outcome that emerged. I also attend to the context within which the case took place and how it influences the interactions that took place between my participant and her audience.

The purpose of the study is to analyze the story of how a Muslim woman confronted health officials about the mysterious disappearance of her baby's body in a way that provoked medical authorities to respond to maternal healthcare challenges. My aim is to examine the way she engaged in resistance and the impact her experiences had on the Ghanaian society.

Furthermore, against the popular larger mobilizations usually discussed in studies on women's activism, this work draws attention to resistance as expressed by ordinary individuals facing complex situations. It also draws attention to an issue that has been given little attention, yet is threatening the lives of many ordinary people in countries such as Nigeria, Niger, and Cameroon. The study thus advances our understanding of resistance to investigate an affected woman's struggles when she is faced with an incident that points to the possibilities of baby theft. By presenting the experience of Suwaiba, the study makes a relevant contribution to research on women's activism and resistance. 


\subsection{Overview}

The study is organized into five chapters. Chapter one comprises an introduction, a background of African women's activism, a statement of purpose and focus, and an overview of the study. The second chapter focuses on the literature review. This section reviews scholarship on African women's activism, highlighting the themes and areas that have been explored in order to establish gaps for my research. Chapter three centers on the methodological framework and methods of analysis. Here, I present an in-depth exploration of the concept of metis to show how I will apply it to my case study. The chapter will end with a discussion of my methods of analysis and data collection. In chapter four, I will analyze the findings from the data. This discussion will be guided by the methodological framework described in chapter three. I will identify the characteristics of metis displayed by my participant, and how these successfully or unsuccessfully worked in her resistance. Chapter five summarizes the study, discusses the implications of the findings, and offers some suggestions for further research. 


\section{Chapter Two: Literature Review}

In this chapter, I review scholarship on African women's activism, focusing on the themes and areas of concern that have been researched in the past two decades. The review focuses on two main aspects of the scholarship; works on women's political participation and expressions of resistance. To better understand the gap that my work will fill, I look at the voices and perspectives of people that have been studied and the frameworks within which their activism has been viewed. Based on my findings, I will show how my work extends the scholarship.

\subsection{Women in Political Activism}

The bulk of research on women's movements in Africa focuses on women's visibility in politics (Tripp et al.; Tripp 1; Tripp 2; Hassim 2; Britton; Goetz; Staudt; Geisler). Scholars have taken a keen interest in exploring the ways women have worked towards increased political participation and policy change. The political engagements of women is a major thematic concern in African women's activism and this has been viewed from different angles. These include: The successes and challenges of women's political movements (Tripp 1), the ways women engage their states on issues concerning women's rights (Hassim 1), and the impact of current events on women's effectiveness in politics (Goetz). Women's participation in politics represents one of the major forces of social change on the continent of Africa. 
The activities of women in politics and the changes they produced have been extensively examined by Tripp et al. in African Women's Movements: Changing Political Landscapes. The book discusses the unique roles activists played in expanding women's rights, lobbying for constitutional reforms and policy change, and transforming African politics as a whole. It provides insight into the multiplicity of factors that enabled these changes, including changing international and regional norms, emergence of autonomous women's movements, and development of regional networks that brought women together to share ideas (Tripp et al. 3). In this work, the authors argue that the political participation of women was critical not only in ensuring that other social arenas are opened to women, but also in changing "the root causes of women's inequality and subordination in society" (Kabira and Nzioki qtd. in Tripp et al. 88).

Significant to women's political activism are the strategies of resistance employed by activists in their quest to realize gender equality in governance. Thus, the Tripp et al. illustrate the nature of the strategies adopted by women in their fight for gender equality in politics. For instance, the authors note that women campaigning for positions in governance used motherhood as a strategy to call for women's inclusion in politics. They observe that women activists used their "traditional positions as mothers as a basis of moral authority from which to argue their inclusion in politics" (Tripp et al. 26). This position was also used as a resource to demand for peace, sacrifice, and justice from political leaders. Though Tripp et al. affirm the criticisms levelled against this strategy, such as the exclusion of women who are not mothers, they recognized its effect as a "rhetorical device" to emphasize women's leadership capabilities. By using this strategy, women reclaimed 
the resourceful and self-reliant meaning of motherhood from its associations with stereotypical traits such as "caregiving" and "sheer decency" (28).

While a significant number of research has been preoccupied with women's political engagements, we can also identify another area of women's participation that scholars have often investigated. This area entails works on the ways in which women respond to sociopolitical challenges as they encounter them. Thus, the struggles and resistance of women in the face of patriarchal domination, war and conflict, environmental destruction, and political upheavals have been of importance to the African women's studies. In what follows, I look at works that discuss some of these struggles and resistance.

\subsection{Writing Women's Resistance}

Recently, researchers have extended knowledge of women's activism by bringing together oral and literary production that expose instances of African women's resistance and the creative ways these are enacted. The collection includes oral testimonies, letters, memoirs, poems, essays, narratives, songs, and court records that starkly present women's struggles within various circumstances. Women Writing Africa, is the first example of such work and it comes in four different volumes: the Southern Region, the West and the Sahel, the Eastern Region, and the Northern Region. The different volumes bring attention to the voices, perspectives, and activities of women as they interact with the forces that pose threat to their lives. The editors of the first volume argue that the book is more than a collection of stories of resistance. Rather, the collection aims to show the "complexity of responses that individual women make to the different situations around them" (Daymond et al. 1). 
The first volume focuses on the narratives of women from the southern part of Africa between the nineteenth and twenty-first century. For instance, one of the cases expounded by the contributors describes Winnie Madikizela Mandela's resistance to the challenges of the apartheid system in South Africa. As a political activist and the wife of Nelson Mandela of South Africa, she was arrested in 1969 with other women and sent to prison for working with the African National Congress (ANC) to end the apartheid system. The women were held captive because of their support for Nelson Mandela, the leader of the ANC organization, who had then been imprisoned. Despite her situation, Winnie Mandela is reported to have taken the opportunity of a public meeting to speak about her experiences and the detention system, though she knew that doing so will likely increase "the risks of rearrest and further banning." In her speech, she implored her listeners to decide whether to "collaborate with the system" or continue to fight for liberation (Daymond et al. 344). By presenting stories such as these, this work demonstrates women's critical role in resistance to oppression.

In another similar undertaking entitled, African Women Writing Resistance, de Hernandez et al. document women's strategies of resistance through various literary production such as poems, stories, oral testimonies, and essays. In particular, this work focuses on contemporary situations, exposing the reader to the ways women have responded to recent and ongoing crises in their societies. For the contributors of this anthology, writing becomes a medium through which women's confrontations with these crises are expressed. They argue that, "writing is essential to effective resistance;" an action of "struggle" that enables them to reclaim their dignity and reveal their challenges to the public (7). Thus they communicate their activism thus, 
If we do not tell our stories, who will know we did not comply:

We did not wish our lives away, but stayed focused,

And staunched the cut of virginal blood,

To stop our daughters being slaves,

We learned to sing survival songs,

Through violence and rape and war;

We did not tell each other lies, or taste slow poison all alone;

And stitched for our dead not effigies, but new dolls

So our artistry shows only prayer heals despair,

Through the things we struggle for $(\mathrm{xx})$.

A central theme that appears to run through this anthology, which also appears to run through various studies on women's activism, is women's responses to political violence and social conflicts. For instance, "A Poem Written in the Ink of the Blood Shed in Rwanda" narrates one woman's attempt to "say the unspeakable," "confront the dichotomies of life," and to find "a way of coping" in the face of the brutalities of the civil war in Rwanda. Revealing the metistic spirit that underscores the motivation for the poem, the writer says, "I write about chaos in order to escape chaos... I describe hopeless situations because I do not want to lose hope (de Hernandez 227). The first and last stanzas of the poem read thus:

A man chops another man's legs with a machete He has to exterminate the Inyenzi, The cockroaches...

A Hutu is killed because he was hiding his Tutsi friends

The beautiful smile of this newborn gives me Hope

The beautiful smile of this newborn

Is the beginning of a New Era (225-226).

In the poem above, the poet used writing as a tool of activism to open a window for readers to see into the violence of the war and how lives are affected by it (219). Though Daymond et al. and de Hernandez et al. insightfully present different situations and expressions of resistance to us, conveying these as literary works limit the extent to which we can fully 
explore the dynamics and processes involved in resistance. Thus we may want to find out, how were the women challenged by the situations they faced, how did they maneuver through these situations, and what outcomes did they achieve. Again, using writing as a form of activism, as de Hernandez argue, excludes the voices of those people who do not have the opportunity to write their stories.

In an article titled, “How Can I Stay Silent?: One Woman's Struggles for Environmental Justice in Lesotho," Braun examines the activism of a South African woman in the context of environmentally destructive projects. According to Braun, Refiloe's activism entails speaking against the adverse impact of the Lesotho Highlands Water Project (LHWP), a multi-dam developmental project in South Africa which started in 1986. The article describes how Refiloe, as a representative of communities displaced by such infrastructure projects, voices their experiences to the organizations involved to draw their attention to the deleterious social and economic conditions they are forced to live with. By doing this, she "lead[s] the struggle to speak out about their experiences and organize[s] impacted people against transnational environmental injustice" (2). According to Braun, as Refiloe strives to use her limited space to show their dissatisfaction of these projects, she challenges "the extra local and elite interests that intimately penetrate her world and reorganize the resources she once called her own." She helped to form a coalition of displaced people so that they can work better to advance their goals (17). This article offers an example of how contemporary women are at the front lines as agents responding to and negotiating the crises they face. 
The emerging visibility of women as agents of change has also been explored by Alidou in her book, Engaging Modernity: Muslim Women and the Politics of Agency in Postcolonial Niger, which explores the responses of Muslim women in Niger to the challenges and opportunity of the twentieth century. In this book we see women who resist domination from Islamic traditions and sociocultural structures in an attempt to realize their own individual interests. Employing Mahmood's conception of Agency, Alidou demonstrates how contemporary Nigerien women have successfully carved out recognized spaces for themselves in the changing sociopolitical landscape they find themselves. According to her "the process has sometimes involved the appropriation and recrafting of characteristics of identity traditionally associated with the male "other" and their mobilization toward particular women centered ends" (4). Thus, she describes for instance, how Malama A'ishatu's knowledge of Islamic poetry gained her a space in the national electronic media and how she seized the opportunity "to transform the received traditions of [Islamic] literacy" and inscribe her voice in the public sphere. Her radio and television programs sought to expand the educational and religious knowledge of her female listeners, who were then limited to specific teachings received from the Qur'anic schools. She also campaigned for the right of girls and women to education. A'ishatu's roles as a media figure and teacher enabled her to participate in the public especially on issues related to Muslim women in a predominantly patriarchal society $(34,38)$.

The studies above illustrate the nature of women's activism and resistance on the African continent and their roles as agents effecting productive change. The majority of these studies have focused on women's activism towards equality in nation-building and governance. Others have also focused on social activism by using writing and narratives as 
medium to bring out women's strategies of resistance to the difficult challenges they face in Africa today. Some too have looked at how women have enacted their agency within oppressive social and cultural structures.

\subsection{Bridging the Gap: A Look at Metis in African Women's Engagement and Resistance}

Though these works demonstrate the burgeoning of women's activism and its impact on their lives and societies, there is little research on activism as enacted by ordinary women facing deleterious circumstances. For instance, most of the voices in these works focus on people who are educated, well-resourced, or even recognized internationally (Tripp et al.; de Hernandez; Alidou; Hassim 1). Only some few studies have looked at ordinary women such as Braun's subject, Refiloe. In addition, there has been more work on women working as organizations or collectives than on individuals negotiating the demands of immediate circumstances. In contributing to the current scholarship, I present researchers with a case of resistance as expressed by an ordinary woman responding to the exigencies of adverse maternal healthcare conditions and practices.

My work is concerned with the ways the average woman negotiates adversities that stem from injurious institutional arrangements and practices. To better understand this phenomenon of resistance, I employ the concept of metis to examine my participant's choices and actions and the impact these produced. The use of this concept opens up a new space in African women's activism in that it has not been used by researchers. Unlike agency which allows us to understand how women become agents of their own interests, 
metis enables us to appreciate how a person navigates, in a flexible, irrepressible manner, forces within a critical situation to create possibilities of change for her own benefits or for the benefits of her society. It is an undeniable fact that women have been resilient in negotiating patriarchal norms, oppression, and violence. However, as a concept, metis has not been fully examined in African women's activism, especially with regard to issues outside the political arena. This work will show how the theory manifests in the case study. In the next chapter, I discuss my method and methodology. 


\section{Chapter Three: Methodology and Method}

I begin this chapter by discussing the transnational feminist discourse that is informing my work. After this, I will discuss the methodological framework, method of analysis, participant, and data collection. The methodological framework will provide an in-depth explanation of the concept of metis and how it operates in the case study. I will explain my method, rhetorical analysis, and how it serves as a useful approach to analyze my findings. The final section of this chapter, the data collection, will explain how I interpreted my data.

\subsection{Introduction}

In this work, I attempt to explore one woman's resistance in response to an issue that is increasingly becoming a threat to the lives of women in Africa today. I do this by examining the rhetorical strategies she employed in negotiating a solution to the problem. In conducting this study, I investigate women's rhetorical practices in the African context—a field that is yet to be explored. As Schell writes, "our maps for feminist and women's rhetorical histories have been drawn and even redrawn from the vantage point of the West" (32). Responding to Grewal and Kaplan's call to "understand the material conditions that structure women's lives in diverse locations" (Grewal and Kaplan 17 qtd in Schell 31), Schell argues that efforts to remap feminist rhetorical histories must be extended to "show transnational linkages across borders (32).

The extension of the borders of feminist discourse to include perspectives that have for a long time been unattended to, is reiterated by Mohanty who asserts that there is the need 
for feminist analytic engagements across multiple identities (250). In line with this, she emphasizes the importance of Third world feminist criticism which according to her "begins from and is anchored in the place of the most marginalized communities of women-poor women of all colors in affluent and neocolonial nations; women of the Third world /South or the Two-Thirds World" (231). This discourse also informs my study, given my subject's social status as a poor Muslim woman.

\subsubsection{Methodology}

In Feminist Rhetorical Resilience, Flynn et al. examine the concept of metis in relation to feminist rhetorical practices. For my work, I employ the concept of metis to examine how African women facing adverse situations negotiate their challenges to potentially bring about change in their lives or in their societies. Metistic strategies, as the authors argue, call attention to one's ability to be flexible, adaptable, and responsive for the purposes of surviving in situations that pose greater challenges than what one can handle (9). Thus, within a hopeless situation, metis offers ideas, methods, intuition, determination, reasoning, and voice to engage the situation in a way that will create possibilities of transformation. Rather than being weighed down by the demands of a situation, a metistic person braces hope that enables her to remain in motion. From these descriptions, metis can be understood as the ability to remain unbowed in spite of adversities.

From the above explanation, it is obvious that agency is an essential part of the current work. My decision to use metis is informed by my belief that the concept embodies agency in itself. This assertion is true in the sense that by engaging metistic strategies, one actually “shapes", "creates," and mobilizes "new possibilities of experience" (Flynn et al. 7-8; 
Dolmage 8). In other words, one becomes an agent of her own interests and goals. This indicates that the nature of metis is one that finds ways to advance her goals amidst constraints. Flynn et al. explain this characteristic of metis as an ability to confront power without aggression, but with "flexible, subtle, active responsiveness to the constraints...of varying circumstances (9). "Flexibility" here entails shape shifting where in order to meet the exigencies of a situation, metis changes form and identity (Flynn et al. 9; Hawhee 49; Detienne and Vernant 21).

In expanding the boundaries of the concept, Dolmage emphasizes that metis is also a strategic approach to engage one's environment, particularly considering that we are in a real world "powered by persuasion, differentiation, shifting contexts, and meaningful bodies" (6). Drawing from Michel de Certeau, he opines that metis delineates how the relatively weak in society form certain tactics "in order to navigate through the "strategies" of institutions and power structures" (6). In the Greek mythology, we are told that the Greek goddess, Metis, having been captured by Zeus and finding it difficult to escape, deploys her ability to change into different forms and this enabled her to slip from Zeus' hold (6). The character of metis then is one that refuses to be subjugated by powerful structures that threaten to silence her capabilities. This ability to shift shapes has been demonstrated by contemporary women at the work place who employed metis as an intellectual ability to successfully navigate terrains dominated by men, and ultimately to prove their expertise (Brady 221-229). Thus, instead of using physical strength, metis combines qualities such as "resourcefulness," "situational intelligence," "wisdom," "vigilance," "shape sifting," and "forethought" to traverse powerful institutions. 
Furthermore, Dolmage writes that the ability of metis to interact with and circumscribe a world characterized by uncertainty is because she works with other forces such as kairos, tuche and techne (121). Kairos is the opportune moment "for steering or "crafting" a product (or an argument)." Tuche is what "brings the indiscernible future within the realm of possibility." Techne connotes the transformation produced by metis. In combining all these forces, metis foresees the possibilities that tuche animates, "harnesses" the opportune moment, and utilizes the creativity of techne to imagine, cut, and build "the tiller itself" (121). In this way, we can say that a metistic person pays close attention to the events of her surrounding to identify opportunities for animating possibilities. I believe also that this characteristic of metis draws attention to an important point. That metis as a character, galvanizes other forces into action for effectiveness. This signifies that metis does not give up, it finds ways to be persuasive and productive.

The foregoing shows that metis can be used in a variety of ways-whether engaged in a struggle, negotiating a challenging situation, resisting domination, or pursuing one's interest amidst obstacles. A critical look at women's movements would reveal that activists have been metistic. Indeed many of the transformations that women across the globe enjoy today have been the results of the work of activists who were unyielding, resourceful, cunning, persuasive, interpretive, responsive, flexible, and hopeful as they struggled for gender equality. These qualities enabled the women to engage in activism and eventually propel social change, and this testifies to the transformative outcomes of these qualities. Recently, scholars have given special attention to examining how metistic characteristics have been demonstrated by women activists to negotiate various challenging circumstances (Schell). 
As this work brings the concept of metis to bear on the case study, it will show how the participant's response to her traumatic situation, provides glimpses of the manifestation of metis in contemporary times. The woman's confrontation with medical authorities reveals her use of metistic strategies that enabled her to engage the forces she encountered. To properly analyze this, I will be asking questions such as: How did Suwaiba employ strategies of metis in her requests for her baby? How are these strategies an expression of her resistance?

\subsubsection{Exploration of Metis in Women's Activism}

Though today's world is far removed from ancient Greek and also from the world of myth, metis still manifests in contemporary times. This can be seen through the activities of women who employ strategies that are in line with the themes of metis to advance their individual goals or those of their societies. Mainly, these women demonstrate the concept as a form of resistance to subvert oppressive structures and norms that oppress them. In Feminist Rhetorical Resilience, Flynn et al. discuss the activities of several individuals, groups of women, and organizations who consciously or unconsciously, have employed metis in their struggle for improved lives and communities. Examples of these women are Vandana Shiva, among others. To better understand the analysis I will be doing in chapter four, I present an example of women's use of metis in the context of activism. My purpose here is to introduce concepts that are apparent in Suwaiba's case and which I will focus on in my analysis. 
It is important to point out two main aspects of metis as will be presented through the story. By showing how contemporary women employ metistic tactics in improving their own lives and initiating progressive social change, two themes will emerge. First, that Shiva, the subject in the story, takes control of her circumstances and develops the capacity to realize her set targets despite the opposition she faced. Even when she was criticized as a result of the environmental sustainability she was seeking for, she remained metistic. Secondly, as a person of metis, Shiva created awareness of both local and global conditions, international projects, and governmental practices that destroy the environment and reinforce oppression of minority groups. Using her case to provide a glimpse of my analysis, I focus on the following characteristics of metis:

- Unyielding attitude.

- Situational intelligence.

- Shape Shifting.

- Ability to create awareness.

- Creating possibilities of change.

Vandana Shiva's advocacy work on the environment employs strategies of metis as a form of resistance. In the article "Vandana Shiva and the Rhetorics of Biodiversity: Engaging Difference and Transnational Feminist Solidarities in a Globalized World," Schell discusses the work of Shiva as an environmental activist whose work focuses on solving ecological crises (37). Schell writes that even in the most oppressive situations, Shiva "recogniz[es] and seiz[es] opportunities for [social change]" (33). Shiva's metis is 
displayed through her use of forethought, shape shifting, adjusting to current situations, and the building of coalition to address economic, political, and environmental issues in India.

For instance, Shiva a shape shifting ability by adopting multifaceted rhetorical principles to effect environmental change (Schell 38). In this regard, her rhetoric assumes different shapes; changing from principles of ecofeminisms, transnational feminisms, and Gandhian philosophy of nonviolence and noncooperation, as and when situations demand. This have provided her with the insight and wisdom to influence "agricultural trade negotiations," to shape "international policymaking," and to spark "coalitions between diverse groups of farmers, environmentalists, public-interest scientists, and concerned citizens" (49). Shiva's shape-shifting abilities in the form of using different rhetorical discourses, have enabled her to engage audiences across multicultural boundaries to bring their attention to destructive environmental conditions around the globe.

Furthermore, Shiva is interpretive. She pays attention to her environment to seize any moment that will aid her environmental advocacy. Displaying the characteristics of Kairos that takes advantage of current events, Shiva identified events that she used as a point of reference in her work: The 1984 genocide in Punjab over changes in agriculture and a gas leakage from a Union Carbide pesticide in Bhopal, India, that killed 3000 people and injured thousands of others (Schell 35). Engaging a metistic endeavor, she seriously began to seek for answers to these tragedies. This action by Shiva portrays her interpretive and analytic ability informed by metis. Her discovery led her to investigate questions concerning violence in agriculture and effects of using pesticides. These helped her to 
identify the issues that needed to be addressed as well as the approaches to use (Schell 35). With these observations, she was able to interrogate "public policies and corporate practices that have led to the devastation of environments and widescale loss of life" (Schell 39).

Another characteristic of Shiva's activism is that she is a "metistic thinker" who draws on contextualized knowledge (situational intelligence) to "meet the exigencies of her circumstance" (48). Though she has been critiqued for not being a good scientist and real farmer, she uses arguments that relate to events and occurrences experienced by the poor people she fights for to overcome those criticisms. This has given credit to her advocacy work of addressing the struggles of indigenous farmers and also allowed her to be successful in spite of the odds.

In sum, Shiva's advocacy is characterized by shape-shifting, interpretiveness, and contextualized knowledge, all of which come together to make her persuasive and maximize her impact on societies, both locally and globally. I will look at the same kinds of characteristics in Suwaiba's case. My purpose is to analyze the way my subject responded to her circumstances, how she negotiated with authorities who were more powerful than her, and how she persuaded people to pay attention to the deleterious situation she experienced. I will do this by looking at the characteristics of metis she displayed in the process of her resistance: Was Suwaiba metistic? If so, how did she express this? How successful was her metis? The purpose of applying this Western concept to study an African woman's activism is to investigate women's rhetorical practices in 
contemporary Africa and the forms these might take. I hope that this will stir conversations about the concept as used by African women activists.

\subsection{Method of Analysis}

I take a rhetorical analysis approach to analyze my data. Rhetorical analysis is an interpretive method that seeks to understand and explain the way people use language to produce particular meanings or persuade an audience. Selzer defines rhetoric as "the means of producing effective discursive acts" (280). Bitzer also adds that rhetoric comes into existence "ultimately to produce action or change in the world" (60), though some critics have argued that this is not always the case (Foss). Hence, a rhetorical analysis can be understood as investigating the process by which a particular speaker engages a specific subject within a specific context. This means that knowledge of the context and the audience of the rhetorical act is required to generate a thorough understanding of the persuasiveness of the act. In short, Selzer defines rhetorical analysis as, "an effort to understand how people within specific social situations attempt to influence others through language... or every kind of symbolic actions (281).

This method is useful to my work because it allows me to analyze the effectiveness of my participant's resistance by examining how her strategies of metis work to persuade her audience. In addition, considering that women's activism aim to influence societal change, using this method allows me to find out if Suwaiba influenced societal change. As Griffin

writes, the field of rhetorical analysis has expanded to include the exploration of historical movements to understand "those efforts which attempt to effectuate change... through 
various persuasive acts" (Griffin 397). To engage in this analysis, I will consider rhetorical factors such as: my participant's actions, the public's response, and the outcomes that emerged. Based on these factors, I develop the following framework of analysis:

- The situation that inspires the rhetorical discourse. As Bitzer argues "rhetorical discourse comes into existence as a response to a situation" (61).

- The Persona—Suwaiba's—rhetorical choices and appeals.

- What resilient strategies did Suwaiba use to reach her audience? How metistic were they?

$\circ$ What arguments and evidence did she use?

- How successful was she in reaching the audience?

- How did her strategies overcome resistance in her audience and why?

- The context within which the confrontation takes place.

- What are the social and cultural assumptions about women in general, and Muslim women in particular?

- How did these assumptions affect the public's attitude towards Suwaiba's outcry?

- The audience.

- Who are they, and to what extent are they aware of the conditions of the Ghanaian health institutions?

- How did they respond to Suwaiba's resistance, and in what way?

- What were the outcomes produced and how did the audience contribute to these? 
Exploring the questions above will enable me to critically think about how successful this rhetorical product (Suwaiba's resistance) was, and the processes that contributed to its success or failure.

\subsection{Participant}

Suwaiba Abdul Mumin is a Ghanaian Muslim woman whose baby was declared dead few hours after delivery but the body could not be accounted for by the hospital staff. This incident provoked her to confront the hospital for her baby's body. After a series of search of the facility, the hospital could still not find the body, neither could they establish any unintentional disposal processes that might have occurred. Determined to have the body to give it a befitting Muslim burial, coupled with doubts about the baby's death, Suwaiba, relentlessly pursued the case. This stirred a national conversation on the issue, which generated critical debates and conversations concerning negative clinical practices and possibilities of baby theft (Essel).

Suwaiba is a Muslim woman who is married with one child. It was her second child that got missing. At the time of the incident, her spouse was away in Cameroon. As a woman, her subordinate position is constituted in the patriarchal society that most African women find themselves. Like many African countries, Ghana practices a culture that subordinates women based on the kinds of roles and spaces they are expected to play and occupy respectively. Her low social status is further reinforced by the public who referred to her as a "poor woman," "vulnerable" woman who doesn't have a voice because she is not "a Minister's wife or relative" (KATH, Where is the Baby?). What these imply is that Suwaiba does not have any recognizable privileges be it class, economic, or education. The 
public also highlighted her religion in their reference to her as a subordinate (KATH, Where is the Baby?). This is because of the stereotypical attitudes towards Muslims as violent people and their women as oppressed.

\subsection{Data Collection}

To conduct my analysis, I collected thirty online news articles on the story from recognized Ghanaian media stations. These stations include Joy Online, Citifmonline, Modern Ghana, GhanaWeb, and Graphic Online. The articles contained narratives of Suwaiba's confrontation with medical authorities, press release from the Ministry of Health $(\mathrm{MoH})$, transcripts of interviews with Suwaiba or her spokesperson, attached audio files of some of the interviews, transcripts and attached audio files of media discussions on the case, and information about public responses to the case. I also collected data from the Facebook page that was formed by the public in support of Suwaiba's struggle. Here, I concentrated on the conversations of the public on the case and the collective petition initiated by the group. The activities took place between February 2014 and August 2014 and so my data focused on the interactions that took place during this period. In order to ascertain the outcomes of this social activism, news articles that emerged later after conversations on the case had subsided were also useful.

To generate a critical interpretation of the data, I first read through the news articles and watched the video files to have a better sense of the story. I also listened to the interview transcripts attached to some of the news articles. After this, I read each material again, this time, paying particular attention to the roles that Suwaiba played in the story, the responses generated from the public, and the responses from health authorities. After this process, I 
identified themes that were in line with the theoretical framework of metis mentioned above. I did this by analyzing how often they appeared in the articles and the emphasis placed on them either in the article titles or in the public conversations (Boyatzis 5). Having identified these, I went over the materials again to identify further details and patterns to allow me to properly develop the themes. For instance, I realized that there was a continual reference to Suwaiba's persistence and continuous demands to health officials to persuade them to find her baby. I categorized this information under the theme, "relentless attitude" to examine how this action enabled her to persuade people to pay attention to the issue. I repeated the process for the rest of the themes. In addition to this, I thematically identified in the public conversations, the problems and concerns that were highlighted in order to better understand how Suwaiba created awareness. The characteristics of metis that emerged from the data are as follows:

- Unyielding attitude.

- Shape shifting.

- Interpretive.

- Ability to galvanize action.

- Creating awareness

- Transforming situations.

This chapter has explained the methodological framework and method to be used for my analysis. In the next chapter, I will analyze the strategies listed above and answer the research questions that have emerged so far. Through the analysis, Suwaiba's demonstration of metistic strategies will become visible. 


\section{Chapter Four: Analysis}

This chapter will first give a contextual background of the location where the event took place. This will be followed by a chronological summary of the case study. After this I will discuss the strategies of metis as identified from the data. This discussion will elucidate how Suwaiba's resistance played out and the significance of her actions.

\subsection{Ghana: A Brief Background}

Suwaiba's case occurred in the Ashanti Region of Ghana, located in the sub region of West Africa. The country's population as at 2014 was 27,043,093 (according to the Ghana Statistical Service population figures). Ghana was formerly colonized by the British and on the $6^{\text {th }}$ of March 1957, it obtained independence from Britain, becoming the first country in sub-Saharan Africa to attain independence. After a series of political upheavals and coups d'état during the early years of independence, the country has enjoyed political stability and democracy since 1992.

Like many African countries, Ghana is challenged with issues, such as economic crisis, poor healthcare, corruption, unemployment, and poor governance. The country's healthcare system, for instance, faces many problems due to retarding economic growth. Problems such as, shortage of medical supplies, demoralized staff, lack of proper health infrastructure, rising infant mortality rate, poor maternal health, expensive healthcare services, and inequalities in service provision, have persisted since the 1970s and 1980s ("Key Health Challenges in Ghana;" Sodzi-Tettey). As usual, women suffer the most from the effects of these health problems such that, a case like Suwaiba's comes quite 
unsurprisingly to some of the Ghanaian citizens. Though there have been considerable improvements over the years, problems still persist which mostly affect the average woman.

\subsection{The Missing Baby Case: A Chronological}

\section{Summary}

News of the disappearance of the bodies of five babies at KATH reached the Ghanaian public on February 13, 2014, when the media reported a protest at the hospital by a group of youth believed to be Suwaiba's relations and sympathizers. According to reports, on February 5, 2014, Suwaiba was one of five mother's whose stillborn baby was declared missing by medical staff at the Gynecology Unit of the hospital. It is important to note here that Suwaiba reported to the media that she did not have a stillborn. That indeed she had a baby boy who was alive, was weighed, and placed on her chest as it is often practiced (Alhassan). Hours after she had been transferred to the "lying in wait" ward to recover, a nurse came to report to her that her baby had passed on. When she requested the body for burial after receiving this information, she is told that the body could not be found (Yeboah).

According to media reports, the woman and her family became suspicious because the baby could not be traced anywhere even after a thorough search of the facility (Owusu-Akyaw). In addition, the accounts of the nurses and cleaner on duty were inconsistent. In light of these events, the woman, in the company of some family relations, continuously visited the hospital after the day of the incident to press the hospital to produce the baby's remains to 
allow them give the body a befitting burial according to Muslim traditions. Joy Online for instance reported that, the mother "is not only grieving the death of her baby but the possibility of not giving the baby a befitting Muslim burial. She is demanding the body of her dead baby and will not relent" (Gadugah). Muslim burial tradition observes that when a person is pronounced dead, the body must be immediately taken by members of the family for the necessary burial rites to be offered. The family's visits were however unsuccessful. It was during one of these unsuccessful visits that sympathizers besieged the hospital facility in protest against their inability to find a body that had been reported dead (Abdulai; Benson). When the protest was publicized, the case stirred up conversations on the media about issues such as professional negligence and the possibilities of baby theft (Yeboah).

This compelled the $\mathrm{MoH}$ to intervene in order to ascertain the cause of the incident. Conversations were even more intensified when the official report released by the $\mathrm{MoH}$ exposed that just like Suwaiba's case, four other supposed stillborns were also missing on the same day (Essel). She and her family realized that this unfortunate event was a common occurrence and that if they did not push it through, they might never have their case listened to. Unlike the other four women who did nothing about the disappearance of their babies, Suwaiba decided to push her demands through instead of accepting to be a victim. Below is an excerpt of the official statement released by the Ghana Health Ministry:

...During her five hours stay on the labour ward, no fetal heart beat recordings were made by the midwives and at 3:50am on the 5 of February, when she delivered and the child was still born. Meanwhile the Doctor on duty constantly recorded fetal heart beat until she delivered and the child was still born. ...the baby was labeled and placed in a box with two other still births delivered that shift in the sluice room for collection the following morning by the morgue attendant. The mother was 
transferred to the post-natal ward when she was stable. Later that morning, two relations of Suwaiba Mumuni arrived at the labor ward to collect her still born baby. They were told to go to the morgue for collection as bodies were not collected directly from the labor ward by relatives. However, when they arrived at the morgue, the attendant told them he was yet to collect the still born baby that morning. The morgue attendant then returned to the ward together with the relatives with the morgue records book for the collection of the still born baby.

...it was then noticed that the box containing the three still births had been taken away. The mortuary record book in the ward did not show any evidence of the bodies having been collected. The orderly on night shift on 4th to 5th of February 2014 was questioned of the where about of the bodies. He admitted he had moved the bodies to the incinerator for cremation. He was asked to quickly bring them back as that is not the regular practice. According to the DDNS in charge, the orderly left and after a while returned to say that he left the box just in front of the door of the incinerator since the door was locked and it was not possible they were incinerated. The nurse in charge of labour and two other staff agreed to come very early in the morning of the 6th of February to meet the orderly for further clarification. At about 6:30am of the 6 of February, the orderly [cleaner] took them to the incinerator room but said he did not hand over the bodies to any specific person. On further questioning he then confirmed he had deposited the bodies at the entrance outside the incinerator room which was at the time locked up. The team requested for the incinerator room to be opened. On entering the room, there was no evidence of recent use of the incinerator. Also it was then confirmed that [the bodies of dead] babies were not incinerated but that the incinerator was purposely for incineration of amputated limbs, placentas, [used] syringes and needles. The box containing the still born babies was nowhere to be found (Essel).

Following the findings of the report, the ministry ordered the doctor and the midwife who were on duty when the incident occurred to proceed on an unpaid indefinite leave. In addition, the 58-year-old cleaner who was alleged to have taken the dead bodies from the ward, was interdicted by the police because he was reported to have handled the stillbirths (Quaicoe-Duho). With regard to the hospital, he Minister for Health, Sherry Ayittey, gave the management of the hospital a two-week ultimatum to account for the bodies of all the missing babies including that of Suwaiba (Essel).

Before the two weeks were up, specifically on March $2^{\text {nd }}$, the Ministry for Gender, Children and Social Protection delegated officials to visit Suwaiba and to assure her of the Ministry's 
support ("Gender Ministry Consoles Suwaiba"). In addition to this action, the Minister, Nana Oye Lithur, "urged the Ministry of Health, the police, the Ashanti REGSEC [police department] and others concerned to, as a matter of urgency, get to the bottom of the issue and other similar cases to unravel the truth" ("Gender Ministry Wants KATH Stillbirth Issue Probed"). However, after the two weeks ultimatum, the management was unable to produce the bodies and the Chief Executive Officer (CEO) of the hospital, was asked to proceed on an unpaid indefinite leave for negligence. This was announced to the public on March 25 2014 (Benson). Two ministerial councils-the Nurses and Midwifery Council and the Medical and Dental Council-were then charged to investigate the issue and produce a report by April 15, 2014 (Benson).

During the council's inquiry in April, Suwaiba, following the unfolding of the case keenly, told media houses that there were attempts by nurses to shift blame to the cleaner who was still in police custody. She explained that the nurses and midwives who appeared before the committee lied in order not to be convicted of any crimes ("KATH baby-missing saga: Mother Battles Interdicted Nurses and Midwives"). She threatened to take the matter to the "African court" to ensure that she received justice.

By this time, political figures, media houses, and the general public had joined in the woman's outcry to pressurize authorities to produce a fair investigative report. For instance, one of the political figures, a Member of Parliament (MP) for Asawase, where Suwaiba's community was located, opined that the official statement was inconclusive. He questioned the validity of reports that the baby was stillborn when the records could not establish this (Gadugah). In addition, other political figures raised concerns regarding the 
attitude of negligence on the part of health authorities, especially towards the poor and less privileged. Some also questioned the silence of women's organizations and activists in the country towards the woman's confrontation (Yeboah).

Furthermore, public support was garnered through a Facebook account which sympathizers had formed to express their concerns about Suwaiba's experience. A Petition website was also formed to collect signatures from the public to endorse a letter that was sent to the Ministry for Gender, Children and Social Protection (KATH, Where is the baby?; http://www.ipetitions.com/petition/facebook-page-for-suwaiba). More so, a group of Muslim sympathizers came together to write a news article to encourage the media and the Ghanaian public to continue with their efforts in pressing the government to take action. For instance, they noted that "we are happy this issue is being given the media coverage it deserves because it bothers not just on perceive[d] complicity but also, a serious breach of human right of a Ghanaian" (Suwari).

In June, 2014, after the investigations, the councils only reported the professional and administrative lapses they identified at the hospital without providing any knowledge of the missing babies. The procedural lapses that were exposed included; a lack of identification mechanism of still-born babies at the facility, poor treatment of maternal mothers (in spite of Suwaiba's weak condition, she was asked to move to the lying ward unattended), and lack of efficient communication between doctors and midwives (QuaicoeDuho; Appiah). Following these findings, on June $17^{\text {th }} 2014$, the MoH transferred the issue to the Attorney General's (A-G) department to handle the criminal aspects of the incident (Mordy). The report quoted the minister thus; 
the Medical and Dental Council extensively investigated the conducts of the doctors involved ...then also we had the Ghana Registered Nurses Association (GRNC) also investigate and they came out with their disciplinary codes as enshrined in the law," $\cdots$

one nurse is still being investigated by the police...because the disappearance of the babies is a criminal act... We've taken action on the administrative part; we've taken action on the management part [but with] the criminal action, we've handed it over to the Attorney General.

In light of the findings, the $\mathrm{MoH}$ asked "management of all hospitals in the country to review existing systems so as to improve performance." In addition, it stated that it was going to develop a "Standard Operation Procedure (SOP) for maternal and child health units in all hospitals in the country" in order to ensure that maternal mothers receive quality healthcare (Owusu). As punitive measures, the councils responsible for the investigation gave one of the two midwives on duty a four-week unpaid suspension and the other a twoweek unpaid suspension. The cleaner was also asked to continue his indefinite leave until the police completed their investigations (see Appendix B).

Despite these outcomes and resulting punitive measures, Suwaiba and her family expressed dissatisfaction over the ministry's conclusions since the baby's whereabouts was ignored in the councils' reports. Suwaiba's spokesperson, her brother, reported that the ministry did not contact them in any way about their conclusions. He stated that, "we are shocked and surprised that the ministry, after failing to contact us on the issue, had issued this report which did not mention the missing baby" (Dapatem). It is important to note here that in spite of the fact that the investigations could not find the whereabouts of the babies, Suwaiba's actions still resorted in a national examination of the maternal health structure. In addition, her actions brought the public's attention to the vulnerability of the ordinary to institutional lapses, which often leave them oppressed. 


\subsection{Analysis}

In this section, I discuss how Suwaiba engaged in resistance by examining the strategies of metis she demonstrated in the event of the incident. I analyze the actions and attitudes she performed in an attempt to realize the goal of finding her baby's body. I also examine how these influenced her immediate audience-health officials—-to pay attention to the struggles of ordinary women as pertains to maternal healthcare. The discussion will be done in relation to the rhetorical questions I posed in chapter three. Thus I will ask, what strategies did she employ and how do they portray metis? What kinds of appeals did she use? How did her audience respond to her? Going back to Selzer's definition of rhetorical analysis as "an effort to understand how people within specific social situations attempt to influence others through language" (281), the analysis will look at how Suwaiba's strategies of metis, performed in response to her situation, worked to persuade her audience. In the end, the section will consider this important question: How productive was my participant?

It is important to note here that a person who uses strategies of metis is resourcefully responsive in a situation in order to open up possibilities of transformation in his/her own life or in his/her society. Shiva's display of metis that I presented in chapter three will guide my discussion. As an environmental activist, Shiva identified the destructive environmental conditions that affected rural women and their societies. She also realized that these situations were not issues that one had to be silent about. This motivated her to lend her voice to the problem and work towards the change she wanted to see. In her activism, she was relentless, interpretive, and productive. In the subsequent paragraphs, I 
discuss Suwaiba's metistic strategies: Unyielding attitude, shape shifting, interpretive, ability to galvanize actions, creating awareness, and transforming situations.

\subsubsection{Unyielding Attitude}

To be unyielding is to be relentless, especially when engaging powerful people or structures. A person of metis is persistent, refusing to give up. She displays flexibility and responsiveness in the face of desperation and impossibility (Flynn et al. 11). This character trait enables the vulnerable to overcome situations despite difficulties. Under this section, I look at Suwaiba's unyielding nature through the narratives surrounding her initial confrontation with medical authorities and her responses throughout the case. In the data I collected, there was a continual reference of her relentlessness, which I would say is the core quality which moved authorities to respond to the issue. 


\subsubsection{Suwaiba and Medical Authorities}

Suwaiba's resistance started with her persistent request, "I want the body of my child for burial." In the media reports that were published when the news first reached the public, Suwaiba's relentlessness in pressing nurses to produce the body they have declared dead was very visible. All the five media houses that originally reported the story captured this theme. For instance, in the media reports that detailed the protest by the youth from her community, she is described thus, "she [Suwaiba] is demanding the body of her dead baby and will not relent" (Gadugah). Also, another report acknowledged her relentlessness as what gave her story publicity, "but the relentless request of madam Suwaiba to see her dead baby, brought KATH to a standstill as she was backed by her family and neighbors in her Zongo community in Kumasi” (Benson).

To begin with, in an interview with Citi News, Ghana, her relentless character was affirmed when she narrated that when she received the news about the baby's disappearance and was told the body could not be found, she refused to settle with the information. According to her, the dearth of information and inaccuracy in the hospital narratives made her and her family suspicious. For instance, she narrated that the hospital initially told her the cleaner had mistakenly disposed the body, but later told her family the body had been sent to the morgue (Naatogmah). She explained, "the way the hospital authorities and everybody involved in the matter are having different sayings I am convinced that my baby is alive" (Naatogmah). In this regard, she calls out the lack of credibility on the part of the hospital, recognizing that their statements are incomplete, if not inaccurate. Hence, she was not 
ready to let the issue go to rest based on the insufficient reasons and explanations presented to her.

Following her suspicions, she requested that a search be conducted to find the body. The search however proved futile as there was no trace of a baby's body anywhere near the facility. In her persistence, some members of her family reported to the hospital to join in the search but that also proved futile, "when our family elders came to the hospital they searched everywhere and could not find the body of my baby who they said was dead" (Naatogmah). It is based on these events that Suwaiba decided to pursue her missing baby case further. Her brother also emphasized to the media, "we will use everything legally to pursue this case; we will do anything that is been backed by law to ensure justice for our sister and everybody in Ghana here" (Naatogmah). Thus, her metis started with her decision not to passively take the information she received unlike the other women who encountered the same situation. Instead of being weighed down by the circumstance, she emerged as a person whose adversity becomes a motivation to pursue further for the desired effect. This relentless character runs through each major aspect of the story as it unfolded.

In the narrative above, Suwaiba's metis is highlighted by her determination to find a solution to her baby's disappearance. In doing this, she identified the lack of accuracy and explanation on the part of the hospital, an action that I consider to be a use of situational intelligence. In addition, she was able to overcome resistance in the nurses she confronted by insisting that she needed the body for burial as her religious practice demanded. By responding to the exigency she faced in this way, Suwaiba resisted being victimized. More importantly, this stance towards her situation provoked responses from the health ministry 
and other ministerial bodies who otherwise might not have intervened. This fact points that by displaying an individual commitment and using situational knowledge to confront the hospital, she created an opportunity to enter the public with her arguments and demands, an event which marked a significant phenomenon of women's activism in contemporary Ghana.

\subsubsection{Shape shifting}

Shape shifting refers to the different identities that women assume to successfully engage the forces they encounter. Detienne and Vernant write that "metis can assume... different identities at once," and Hawhee adds that it is this ability that leads her to effectiveness $(307 ; 49)$. When women use shape shifting, they consciously or unconsciously take on different personas. That is, they assume different identities other than what they are perceived to be in order to become effective within a particular situation or activity. For instance, Brady shows how women working in male dominated organizations used shape shifting to "overturn essentialized gender constructions and establish themselves at the nexus of work group boundaries" (211). In this manner, the women employed different behavioral tactics to construct their own authorities to enable them overcome subordination from male colleagues (224). In what follows, I examine how Suwaiba shifted form as she publicly negotiated her situation. 


\subsubsection{Public Statements}

Suwaiba shifted shape by not conforming to stereotypical expectations of women, especially women of her social status. Against the medical report that her baby was dead, she maintained that, "I am confident my baby is alive" (BBC). As the media granted her interviews, she used narratives of her experiences at the hospital to challenge authorities. In her public statements, she constructed an argument that questioned medical reports and arrangements. These actions digressed from cultural conventions about how women are expected to behave and relate to authority. Indeed Suwaiba talks back to authority. Furthermore, by emphasizing her confidence, she did not conform to feminine traits such as passivity, soft, submissiveness, and lack of self-confidence. Instead, she negotiated with authorities by drawing her own conclusions based on the inability of the hospital staff to validate their reports. Her words suggest that she used an appeal to logic to show why she was confident about her counterclaims to reports that her baby was stillborn:

My son is not dead; he is still alive... They did not show the dead body to me. Besides, since that time they have not been able to produce the body. This shows that my baby is alive.'

Suwaiba used the argument above to arrive at a number of conclusions that she based her confrontation on: the accounts presented by the hospital staff were inconsistent and the statement by the $\mathrm{MoH}$ indicated that the baby was stillborn when this could not be accurately proven (Naatogmah). What she does in the statement above is to use the facts of the situation to contest medical information.

While Suwaiba becomes a woman who talks back in order to have her concerns addressed, her words indicated the subject position she assumed in her public interactions. She stated 
elsewhere that, "the only news I am expecting to hear is that my baby has been found" (BBC). By being this assertive, she changes identity as an ordinary woman rendered without a voice, to a person who becomes an agent of her own desires. This point is further highlighted by how she is described by the general public. While they recognized that she is "poor" and "ordinary," they also acknowledged that she is a woman who refuses to be "intimidated" (KATH, Where is the Baby?). This assertion further strengthens her shape shifting abilities. I would argue that this shape shifting ability is what enabled Suwaiba to invade the public and attract the attention she got. A metistic person, like the Greek goddess, Metis, shifts through different forms to achieve effect. In the same manner, Suwaiba, as subordinate as she is, assumed the shape of a strong and confident woman to enable her to compel the hospital to account for her baby.

As I mentioned in the discussion of my methodology, metis embodies agency in its strategies and characteristics. This leads us to metistic agency, which can be understood as the ability of the relatively weak in society to negotiate, through various responsive actions, challenging situations and forces (Hawhee 47) or powerful institutions and structures" (Dolmage 6). By engaging perseverance and shifting shapes in order to move health authorities to respond to her situation, Suwaiba became an agent of her own desires in hope of improving her situation. In addition, by questioning medical reports, she negotiated the institutional operations and conditions that led to her adversity. Thus, when the host of a TV discussion on the incident questioned if Suwaiba's claims and actions might influence other people to stage similar confrontations against the hospital, Professor Attafuah, a human rights advocate responded: 
...If it will open the floodgates [then] let the floodgates be opened and let the floodlights be thrown on them so that we'll have more transparent accountable procedures for responding to the challenges that irk many ordinary people, but who do not have the wherewithal, to challenge the authorities that they believe did not treat them fairly (Mordy).

As the above reveals, Suwaiba's appeal called forth an eloquent response that was viewed by a public audience. In addition, the statement emphasizes the empowering implications of Suwaiba's metistic actions in creating an opportunity for people with similar cases to be encouraged to speak up. She also created an opportunity for accountability and transparency on the part of governmental institutions. A critical consideration of the question that incited Attafuah's statement would reveal the fear for female agency as recognized by Dolmage. Dolmage refers to this as social and institutional fears of female agency, as symbolized by the swallowing of the Greek goddess, Metis, by Zeus to subdue her abilities (Flynn et al. 10). This phenomenon offers an insightful parallel to the current case in the sense that, since Suwaiba's outcry and actions were not culturally womanly, nor common in contemporary Ghana, her outcry was initially looked upon as a threat to the institution.

In sum, Suwaiba displays shape shifting by assuming a persona that digressed from traditional and social gender roles and expectations of a woman. Venturing the public space as an ordinary, she moved into a different identity to be able to persuade her listeners. This indicates that she adapted to the traits usually associated with the public sphere, such as boldness and assertiveness. 


\subsubsection{Interpretive}

A metistic person is interpretive. By this, I refer to a person's ability to analyze her situation in order to look for ways to overcome the forces encountered. Detienne and Vernant make us understand that metis is displaying "a continuous concentration on an activity (or situation) that is in progress" (parenthesis mine) (14). What this means is that metis keeps an awareness of her environment. This allows a person to understand her situation or the issues that obstruct her to be able to negotiate a way out or take action.

Suwaiba displayed this quality when she intervened in the investigation proceedings to draw the public's attention to the fact that the nurses who appeared before the investigative committee shifted blame on the cleaner (who had been held in police custody) to avoid being found guilty. Her statement indicates that she realized the nurses' attempt to implicate the cleaner in the incident an action that might negatively affect the results of the investigation. She says,

I want the body of my child. Whatever they have done with the body, they will walk up to this place bare-footed.

I realized they don't believe in the Bible they sworn by, so wherever I will take them, I will do. Especially, all those nurses. Now, they are pushing the blame on the cleaner (orderly). If they knew what they said was true, they could have brought the cleaner ("KATH Baby-Missing Saga: Mother Battles Interdicted Nurses and Midwives").

In the above quotation, Suwaiba explains that because the cleaner was not present at the council, the nurses decided to push the cause of the babies' disappearance on him. Suwaiba's observation here is significant in that she points out the uncooperative attitudes of the nurses towards the issue. Thus, she becomes more suspicious of their actions and voices her mistrust of the hospital staff, "whatever they have done with the body." In 
essence, she simply wanted her baby because she didn't trust them. This woman's attempt to subvert the hospital's practices is pretty clear. The significance of this action is that it brought the nurses and the hospital at large into the open for public scrutiny. More importantly, by exposing the nurses' uncooperativeness, the exigency and severity of the occurrence are vividly brought out. Though she is not educated, Suwaiba's statements indicate that she was attentive to the conversations as they progressed, allowing her to take action when situations demanded so. This responsiveness reinforces her interpretive attitude.

\subsubsection{Ability to Galvanize Action}

In "Breathe Upon Us an Even Flame: Hephaestus, History, and the Body of Rhetoric," Dolmage writes that "through close alliance with kairos, tuche, and techne, metis interacts with and circumscribes the world of chance and opportunity" (121). In chapter three, I explained that this feature of metis signifies an ability to garner forces or support to achieve maximum effect within a particular activity. To analyze this strategy, I discuss how Suwaiba's struggles with the hospital inspired the public to join in her activism. It is evident that Suwaiba's story created an opportune moment that brought people together to fight for justice as pertains to the situation. I look at the conversations from the public and the actions that they undertook in response to the event. 


\subsubsection{Responses from Political Figures}

When news of Suwaiba's missing baby and the hospital's failure to produce the body reached the public, government officials were persuaded to add their voices to her outcry. Her impact on the officials stemmed from the fact that they are not unaware of the kinds of problems that exist in the Ghanaian healthcare system. However, Suwaiba's story reinforced the existence of those problems and the extent to which individuals are adversely affected by them. Besides, her determination to press for answers persuaded people to seek accountability and responsibility on the part of health officials. In this light, Radio Gold's Alhaji and Alhaji program, brought politicians together to discuss the concerns that emerged from the incident and show their support for the mother. They raised concerns regarding the possibilities of baby trafficking; "or is it the case that our professionals in the health sector have been corrupted by cabals who are engaging in stealing and selling offspring? I don't know, this is a very serious matter..." (Yeboah). Others also saw the need to address professional negligence based on the inconsistencies in the stories by the hospital; "let us get to the bottom of this by emphasizing the factor of negligence as opposed to the factor of criminality because we can still arrive at any evidence of criminality through investigating negligence" (Yeboah). The vulnerability of ordinary women to injurious institutional practices and the lack of ignorance on the part of most women were highlighted; "because the people who have been told that they have lost their children at birth are uneducated at least beyond the four walls of education, possibly do not know their rights, possibly do not know that even if your child is dead you need to see that dead child. How many families have been told this?" (Yeboah). 
The significance of the concerns above as they surfaced in the course of the conversations is that Suwaiba's struggles was not just an individual woman's struggles. She brought influential voices together to discuss pertinent issues that have been deleterious to women's health as I indicated earlier in this chapter. This aspect of her resistance is what I associate with metis in the form of galvanizing forces to negotiate her situation. Furthermore, the articulation of these issues by politicians gave an added impetus to Suwaiba's activism since her story reflected problems stemming from poor governance. This means that her story appealed to a broader problem embedded within the current state of affairs in neocolonial Ghana. Finally, with stories of increasing baby trafficking in Nigeria, her activism appealed to the context within which the issue occurred and people were influenced to support her.

\subsubsection{Responses from the Public}

Further emphasizing how Suwaiba's galvanized action to intensify her activism, is the online activism that was formed by her community (KATH, Where is the baby?). This activity marked the first time in contemporary Ghana that the internet, specifically Facebook, was used to mobilize efforts to mount pressure on the government to address maternal healthcare. The participants, having gathered signatures from the public, also wrote a petition to the Ministry of Gender, Children and Social Protection, demanding accountability and justice for Suwaiba and the other mothers whose babies were also missing. They insisted that investigations on the case be carefully monitored to achieve the best results (see Appendix C, fig. 3.; http://www.ipetitions.com/petition/facebook-pagefor-suwaiba). 
The activities of the group were also reported by the media and that reinforced their actions. Some of the themes that were exposed in the conversations on the online platform include, equal rights for all women, poor governance, injustice of the poor; improved maternal healthcare, and professional negligence. For instance, in a visual that had the Coat of Arms of Ghanaian placed in the middle, there was the inscription, "every woman, regardless of Religion, Ethnicity, Social class or Literacy level, can go through pregnancy and childbirth in respect, Dignity and Care without her Human Rights being compromised" (see fig. 1). Also, against a blurred image of Ghana's national flag, a statement reads, "this is how Suwaiba and many others failed by our institutions see Ghana... blurred!" (see fig. 2). This statement emphasizes the failures of the country's government not only with regard to health, but in other institutions as well. Another statement goes thus, "the watch words are responsibility and accountability. Speak up for maternal health, human rights and dignity." Another supporter also had this to say, "imagine she was a minister's wife or relative is dat how $\mathrm{d}$ case wud hv been treated? Abaaaaaaa Ghana where aa we headin 2? We need justice" (KATH, Where is the Baby?). 


\section{Freedom and Justice:}

Every woman, regardless of Religion, Ethnicity, Social class or Literacy level can go through Pregnancy and Childbirth in Respect, Dignity and Care without her Human Rights being Compromised.

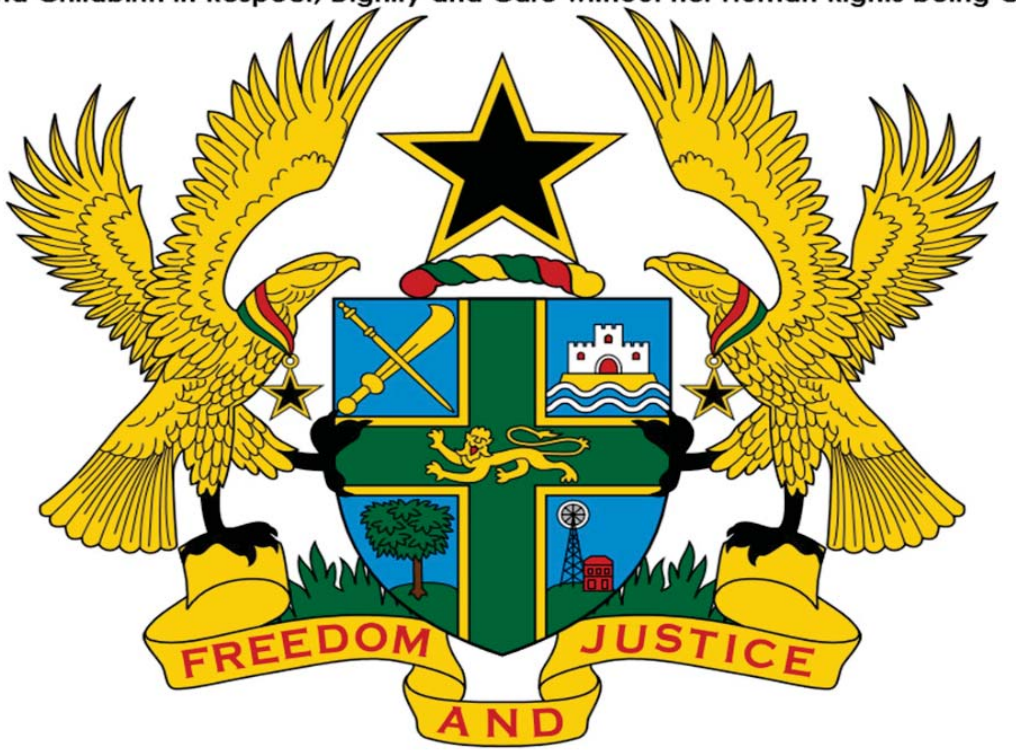

This is our definition. If you believe in this too, Join us.

Fig. 1. A photo from the Facebook page, KATH, Where is the baby?, appealing for the public's support in signing a petition to the President to request justice for Suwaiba. ;

“KATH, Where is the baby?” Facebook. Facebook, 2 March 2014. Web. 26 May 2014. 


\section{There is nothing wrong with the sharpness of this picture!}

As we celebrate our liberation from oppression on 6th March, one lady would be asking the President if she is Ghanaian enough and why she should celebrate. Millions of us feel same.

This is how Suwaiba and many others failed by our institutions see Chana... blurred!

If you can't see this image sharp enough, then maybe you share a similar story. We are joining the young lady to ask our president ... WHY? You are invited! Sign the petition by clicking the link...

Fig. 2. A photo from the Facebook page, KATH, Where is the baby?, showing the participants' support in demanding justice for Suwaiba. ; "KATH, Where is the baby?"

Facebook. Facebook, 27 February 2014. Web. 26 May 2014.

The discussion under this section illustrates the ways in which an individual's choice to be proactive in the face of trauma spurred others on towards the same course. In this manner, Suwaiba's actions initiated a national activism for an improved healthcare, institutional accountability, and justice for the poor. As a metistic figure, she galvanized a collective activity though she started as an individual. This phenomenon is very significant especially within the African context where one might not always have the advantage of an established organization. Besides, in a situation where no women's organizations and activists surfaced to take up this critical matter, Suwaiba's individual efforts played a major 
role in stirring up a public outcry to create the kind of atmosphere that would cause health and government officials to act on her case. As Dolmage argues, by engaging other forces, metis is able to act more effectively (121). This is clearly manifested in Suwaiba's activism through the way the public takes up her story to present it more forcefully to the authorities involved.

\subsubsection{Creating Awareness}

Brady writes that the resistance of metistic women "opens up possibilities for progressive social change" (212). In this sense, a person of metis resists domination from powerful structures in a way that creates awareness of problems that need to be addressed. Hawhee writes that, metis is "a mode of knowledge production" (48). One that informs its subjects and exposes them to critical ideas and information that emerge out of a particular situation. Here, I identify how Suwaiba's resistance created an awareness of critical issues regarding maternal healthcare. I also analyze the extent to which these issues opened up opportunities for progressive social change with regard to maternal healthcare in Ghana.

One of the major reasons why this case is significant is that Suwaiba's resistant actions exposed certain critical issues about maternal healthcare and institutional practices as identified in the section above. However, as I mentioned earlier, some of these problems are known to the Ghanaian society. Therefore, she reinforced their knowledge and existence, and how if unchecked, they can negatively affect individuals and their families. Worthy of mention here is that though there is no evidence as to whether the case is a baby theft issue, her persistence for the matter to be probed cautioned Ghanaians towards such 
issues. This is to say, by exposing the nature of institutional lapses and negligence (as the investigative reports and hospital accounts revealed), her story informs us of the conditions that breed child trafficking. Indeed Suwaiba created an awareness on different levels of issues; maternal healthcare, increased child mortality, work ethics, impact of poor governance on social institutions, and the challenges faced by poor women who do not have the resources to seek quality healthcare. She was metistic, which in the media's attempt to describe the issues that her actions exposed, stated that, her "fight for her missing baby... has opened a can of worms" (Modern Ghana.com). Suwaiba's case and all these issues come together to create an opportune moment for change. This idea is also attested by the Minister for Health who described the issue as a "test case" for health officials to transform its practices (Donkor). Thus, it is up to the leaders of the nation, the ministry in charge of gender, and women's organizations to use this woman's experience as an argument to push for reformation.

\subsubsection{Transforming Situations}

Under this section, I return to the final question I posed under my methods; to what extent was Suwaiba's resistance productive? By this, I analyze if and how Suwaiba's actions opened up possibilities to transform the status quo; to revise or make adjustments to existing practices, procedures, conditions, and professional attitudes within the health institution. As Flynn et al write, metistic strategies create opportunities that can be seized to bring about transformation (Flynn et al. 9).

Based on the outcomes that emerged from Suwaiba's fight for her baby, I would say that she played a role in opening up an opportunity for the Ghanaian health ministry to improve 
upon its institutional practices and arrangements. First, Suwaiba's constant demands compelled the $\mathrm{MoH}$ to conduct investigations to find the cause of the occurrence. As the data I collected attested, "it took her insistence and the solidarity of others" to stir a national examination of maternal healthcare and procedures in existence (Modern Ghana). Thus she was exigent. Though this action did not produce her baby as she desired, her actions challenged the hospital to take the necessary measures that will militate against such incidents. On June, $23^{\text {rd }}$, the hospital announced that it was going to review its operational standards including the development of operational guidelines and improved staff supervision and training "to restore public confidence in the hospital" (Acquah). Though this response is only a promise, the response is significant in that we see a gradual step towards transformation of the hospital. Furthermore, two months after the investigations, the management of the hospital launched the establishment of "a new six-bed intensive care unit" at the Obstetrics and Gynecology unit of the hospital to help manage complicated maternal cases. Clearly these responses begin a transformative experience for women and the society at large.

Another transformative outcome of Suwaiba's resistance is that she became an agent of her own interests. As we can see from the analysis above, by choosing to negotiate a solution to the adversity she faced, she resisted being victimized by the institutional arrangements that contributed to her loss. In this light, she exercised agency by developing the mental capacity to engage medical authorities in spite of the powerful people involved. Her public statements enabled her to reach the public. She used her persistence to compel health officials to attend to her concerns and those of maternal healthcare in general. Again, she refused to remain silent over her adversity and instead, challenged the status quo. As I 
stated in chapter three, a person of metis shapes and creates "new possibilities of experience" in her life, an outcome that Suwaiba's activism produces on her own identity (Dolmage 8).

Finally, an important aspect of how productive Suwaiba's resistance was is that the people who joined in her activism seized the opportune moment (the disappearance of the babies) to press the Ghanaian government for improved maternal healthcare. Suwaiba's experiences, coupled with the lapses revealed in the report, became significant evidence around which the public rallied to speak against injurious clinical practices. In this regard, the public was effective in seizing the kairotic moment. For instance, the Facebook comments included statements such as; “...It's [the situation] been going on for far too long" and "...Mother Ghana. When can you start fighting justice for the vulnerable and the Marginalized group?" (KATH, Where is the Baby?).

In conclusion, the above analysis has illustrated how Suwaiba employed strategies of metis as she engaged in resistance. As a person of metis, she was relentless in getting her concerns attended to. She also shifted shapes by not conforming to cultural conventions about marginalized women. Instead, she confidently voiced her concerns and engaged the general public through her public statements. By so doing, she galvanized public support to pressurize health officials to ensure that the issue is properly addressed. As a metistic person, she created awareness of institutional negligence and poor maternal healthcare. Finally, by being productive to call forth significant responses from the government, she became an agent of her own interests. Though her baby was not found, Suwaiba's activism opened up possibilities for progressive social change. Indeed she was metistic. 


\section{Chapter Five: Conclusion}

In this conclusion, I will discuss the implications of the study in relation to how my findings contribute to research on women's activism in Africa. I will also revisit the purpose of the study that I stated in chapter one to show how that has been accomplished. Finally, I will discuss the significance of the study and offer recommendations for future research.

\subsection{Extending the Boundaries of Women's Activism}

This work has analyzed Suwaiba's resistance through an examination of her metistic strategies. A major implication of this study is that it does not just explore the individual's abilities. It equally shows how the individual's efforts can be effective in garnering public support for activism. In this sense, the analysis illustrated how Suwaiba's persistence moved people to respond to the issue with and for her. This kind of solidarity as seen from the analysis, began with the individual's choices and determination, which influenced others to take actions that were geared towards transformation. In addition, metis allows us to explore diverse skills such as flexibility, vigilance, wisdom, forethought, and shape shifting that are useful qualities for effectively negotiating difficult situations. Furthermore, the concept allows us to examine the extent to which women create awareness or attempt to transform their situations through the actions they undertake. In the current case study, Suwaiba's metis produces three major effects: 
- She created new expressive possibilities for herself by resisting victimization and becoming an agent of her own interests.

- Her outcry incited a public action; thus people who share in her concerns were motivated to voice their opinions and this maximized pressure on the government to pay attention to the issue.

- Her activism created awareness of the prevalent injurious nature of maternal healthcare structures and compelled health authorities and stakeholders to finally respond towards the situation.

This research has also examined how and the extent to which minority women can put themselves forward to speak. Based on the findings of this study, I wish to suggest that metistic strategies have offered a way for this ordinary woman, Suwaiba, to speak, act, and provoke productive social change. As demonstrated in the analysis, Suwaiba's ability to shift shapes, to not conform to cultural expectations of women of her religious and social status, enabled her to assert her concerns in the public. Her persistence also allowed her to garner attention in the media in a way that compelled authorities to respond to the issue. What is important here is that through her outcry, Suwaiba plays a role in motivating authorities to address the institutional failures and conditions that maternal mothers and their families have been subjected to. This outcome, though not revolutionary, is worth considering as a way of recognizing the grassroots efforts that create opportunities for productive social change to improve the conditions of women's lives. The study thus leads us to encourage women to not give up their struggles for change. 


\subsection{Significance of the Study}

A major significance of this work is that it has extended the boundaries of African women's activism on three levels. First, as discussed in chapter one, scholarship on women's activism has focused more on women's political engagements than on social activism. In addition, the women involved in such works are usually educated, well-resourced, and sometimes internationally recognized. Also, works on women's resistance has tended to be more interested in larger mobilizations and in the activities of organizations. In contrast with these popular forms of activism, this work has offered researchers the opportunity to explore the participation of an ordinary woman in resistance. Thus, Suwaiba's response to her situation opens us up to rethink the meanings of resistance and activism, and the forms these might take. With regard to the theory, this study opens a space for researchers to explore the ways in which metis can be useful to contemporary African women's studies. More importantly, it gestures scholars towards the need to further explore the everyday resistance of average women, to recognize their efforts.

Another significance of the study is that it has created an opportunity for researchers to investigate the rhetorical practices of African women. It has attempted to respond to Schell, Grewal and Kaplan's call that feminist rhetorical theories and practices should be extended to include transnational contexts (Schell 32; Grewal and Kaplan 17 qtd. in Schell 31). As I have discussed earlier in this chapter, the findings of the study show the interesting contribution that Suwaiba's case for instance, makes to African women's resistance, illustrating how the individual's metistic efforts incite collective action to push for social change. Through this work, I have offered an example of how feminist rhetorical theories play out within the African context. We usually look at agency when we discuss women's 
resistance, but this work has showed how concepts such as shape shifting, situational intelligence, and interpretiveness help us to better understand women's participation. My discussion of women's engagements over the years, in chapters one and two, shows the use of some of these rhetorical concepts by African women. Therefore, considering all of these reasons, this field has many insights to offer if explored.

\subsection{Future Research}

With the evidence that many individual women are actively negotiating their difficult situations in diverse ways (de Hernandez et al. 3; Nigerians Talk 7), there is the need for more scholarship in this area. First I recommend that a field research be conducted to look at how marginalized women respond to and overcome the contemporary social issues they encounter. A work such as this can produce insights beyond the findings of the current study since the researcher will have the opportunity to work closely with the women being studied. Researchers can look at what motivates them, the obstacles they face in the process, the degrees to which they succeed, and the impact their engagements have on other women. The researchers could also even look at which means of activism are commonly employed and if the success of speaking out is in anyway influenced significantly by such factors as the level of education, social status, and economic status of the women. A work like this would be important because we normally hear about women who are being resilient in diverse ways on the media, where the impact of such efforts are not fully captured. As a scholarly work, researchers will have the space to better elaborate and examine the dynamics of these efforts for people to learn from them. 
I also recommend that work can be done to explore African women's rhetorical practices. We can start such a work by examining the work of different individuals such as Wangari Maathai of Kenya, Ellen Johnson Sirleaf of Liberia, and Leymah Gbowee of Liberia, to identify the successful ways they handled various social issues. Though women's strategies of resistance and means of engaging their dominant structures have been discussed by scholars (Tripp et al.; Tripp; Hassim), these are usually mentioned as sub-sections. In this regard, we cannot fully appreciate their effectiveness. Producing an extensive knowledge of women's rhetorical practices will be an invaluable resource to African studies. This scholarship can even be furthered by conducting a comparative study of African and Western women's rhetorical practices to bring out the varying contexts and perspectives that characterize these two discourses. This will enrich our understanding of what feminist themes such as agency, empowerment, transformation, and development mean for the African woman in contrast to the Western woman, to enable us engage in the kinds of transnational linkages and solidarity scholars have been gesturing toward. 


\section{Works cited}

Abdulai, Iddrisu "Ministry of Health erred in the 'missing' baby saga."

Spy Ghana. 2 Mar. 2014. Web. 12 Jan. 2014.

http://www.spyghana.com/ministry-health-erred-missing-baby-saga/

Acquah, Faustine Sakwaba. "KATH to review operating procedures following missing baby scandal." Joy Online. 24 June 2014. Web. 23 Sept. 2014.

http://www.myjoyonline.com/news/2014/June-24th/kath-to-review-operatingprocedures-following-missing-baby-scandal.php

Alhassan, Issah. "The Missing Still Born Baby Saga, The Inside Story." The Chronicle. 21 Feb. 2014. Web. 25 May 2014. http://thechronicle.com.gh/the-missing-stillborn-baby-saga-the-inside-story/

Alidou, Ousseina D. Engaging Modernity: Muslim Women and the Politics of Agency in Postcolonial Niger. University of Wisconsin Press, 2005.

Arnfred, Signe. "Women in Mozambique: Gender struggle and gender politics." Review of African Political Economy 15.41 (1988): 5-16.

Appiah, Salomey. "KATH missing baby saga: CEO asked to proceed on leave." Graphic Online. 26 Mar. 2014. Web. $28 \quad$ Feb. 2015 http://www.graphic.com.gh/news/general-news/20143-kath-missing-baby-agaceo-asked-to-proceed-on-leave.html\#sthash.YRW19CKv.dpuf

Benson, Ivy. "KATH Baby Missing Saga: Health Ministry Axe Hospital CEO." Joy Online. 25 March. 2014. Web. 23 May 2014.

Bernstein, Lisa and Ndinda, Catherine (2008). Introduction: Women's Activism for Gender Equity in Africa. Journal of International Women's Studies, 10(1), 1-4.

Bitzer, Lloyd F. "The Rhetorical Situation." Philosophy \& Rhetoric (1992): 1-14.

Brady, Ann. "Interrupting Gender as Usual: Metis Goes to Work." Women's Studies (2003): 211-33.

Braun, Yvonne A. “How Can I Stay Silent?: One Woman's Struggles for Environmental 
Justice in Lesotho.” Journal of International Women's Studies 10.1 (2013): 5-20.

Britton, Hannah. Women in the South African Parliament: From Resistance to

Governance. University of Illinois Press, 2005.

Britton, Hannah E. "Coalition Building, Election Rules, and Party Politics: South African Women's Path to parliament." Africa Today 49.4 (2002): 33-67.

"Ghana hospital given 14 days to find 'missing babies" British Broadcasting Corporation. 28 Feb. 2014. Web. 26 May 2014. http://www.bbc.com/news/world-africa26382532

Boyatzis Richard E. Transforming Qualitative Information: Thematic Analysis and Code Development. Sage, 1998.

Clare, Maria, et al. "" You Keep Yourself Strong": A Discourse Analysis of African Women Asylum Seekers' Talk about Emotions." Journal of International Women's Studies 15.1 (2014): 83-95.

“Gender Ministry wants KATH stillbirth issue probed." Graphic Online. 24 Feb. 2014.

Web. 23 May 2014. http://www.graphic.com.gh/news/general-news/18147gender-ministry-wants -kath-stillbirth-issue-probed.html

Dapatem, Donald Ato. "KATH missing baby: Family unhappy with MoH report." Graphic Online. 16 June 2014. Web. $25 \quad$ Jan. 2015. http://www.graphic.com.gh/news/general-news/25234-kath-missing-baby-familyunhappy-with-moh-report.html

Dapatem, Donald Ato. "Suwaiba determined to seek justice for her 'missing' baby."

Graphic Online. 14 June 2014. Web. 5 Jan. 2015. http://www.graphic.com.gh/news/general-news/25177-suwaiba-determined-toseek-justice-for-her-missing-baby.html

Daymond, Margaret J., ed. Women Writing Africa: The Southern Region. Vol. 1. Feminist Press at CUNY, 2003.

de Hernandez, Jennifer Browdy, et al. "African Women Writing Resistance." China \& Africa 12 (2011): 035.

Detienne, Marcel, and Jean-Pierre Vernant. Cunning Intelligence in Greek Culture and 
Society. Hassocks: Harvester Press, 1978.

De Waal, Maretha. "Globalising the Women's Movement Agenda in South Africa." Agenda 19.64 (2005): 117-126.

Dolmage, Jay. "" Breathe Upon Us an Even Flame": Hephaestus, History, and the Body of Rhetoric." Rhetoric Review 25.2 (2006): 119-140.

Dolmage, Jay. "Metis, mêtis, mestiza, Medusa: Rhetorical bodies across rhetorical traditions." Rhetoric Review 28.1 (2009): 1-28.

Donkor, Kwadwo Baffoe. "Corporate organisations urged to set up crèches." Graphic

Online. 20 Mar. 2014. Web. 28 Mar. 2015. http://www.graphic.com.gh/news/general-news/19758 -corporate -organisations-urged-to-set-up-creches.html

Gadugah, Nathan. "KATH missing baby saga: What happened to our baby?" Joy Online. $28 \quad$ Mar. 2014. Web. $23 \quad$ May 2014. http://www.myjoyonline.com/news/2014/march-28th/kath-missing-baby -sagawhere-is-our-baby-muntaka-asks-minister.php

Goetz, Anne Marie. "No Shortcuts to Power: Constraints on Women's Political Effectiveness in Uganda." The Journal of Modern African Studies 40.04 (2002): 549-575.

Essel, Isaac. "Health Ministry Gives KATH 14 Days to Produce 5 Babies Declared Dead." Joy Online. 27 Feb. 2014. Web. 23 May 2014.

http://www.myjoyonline.com/news/2014/February-27th/health-ministry-giveskath-14 days-to-produce-5-babies-declared-dead.php

Essel, Isaac. "Parliament demands missing KATH babies' report." Joy Online. 17 June 2014. Web. 26 August 2014. http://www.myjoyonline.com/news/2014/june17th/parliament-demands-missing-kath-babies-report.php

Fanon, Erantz. A Dying Colonialism. New York: Grove. 1959.

Flynn, Elizabeth A., Patricia Sotirin, and Ann Brady. Feminist Rhetorical Resilience. “O'Reilly Media, Inc.”, 2013. 
Foss, Sonja K. Rhetorical Criticism: Exploration \& Practice. Long Grove, IL: Waveland Press, 2009.

Griffin, Leland M. "The Rhetoric of Historical Movements." Quarterly Journal of Speech 38.2 (1952): 184-188.

Gyasiwaa, Adwoa. "GMA backs investigation into KATH missing babies' saga.” Joy Online. 5 Mar. 2014. Web. 26 June 2014. http://www.myjoyonline.com/lifestyle/2014/March-5th/gma-backs-investigationinto-kath-missing-babies-saga.php\#sthash.5d6OjhRL.dpuf

Hassim, Shireen. "Terms of engagement: South African challenges." Feminist Africa 4 (2005): 10-28.

Hassim, Shireen. "Voices, hierarchies and spaces: reconfiguring the women's movement in democratic South Africa." Politikon: South African Journal of Political Studies 32.2 (2005): 175-193.

Hawhee, Debra. Bodily arts: Rhetoric and Athletics in Ancient Greece. University of Texas Press, 2004.

Hughes, Melanie M. "Armed conflict, International Linkages, and Women's Parliamentary Representation in Developing Nations." Social Problems 56.1 (2009): 174-204.

“Petition Facebook Page for Suwaiba.” ipetitions. Ipetitions, Feb. 2014. Web. May 28, 2014. http://www.ipetitions.com/petition/facebook-page-for-suwaiba

“KATH Missing Baby Must be Found, Dead or Alive - Deputy Minister." Daily Graphic. Feb. 22 2014. Web. 20 May 2014.

“KATH, Where is the Baby?” Facebook. Facebook, 25 Feb. 2014. Web. 26 May 2014.

"Key Health Challenges in Ghana." http://www.accanet.com/content/dam/acca/global/PDF-technical/health -sector/tech-tp-khcg.pdf

Mohanty, Chandra Talpade. Feminism Without Borders: Decolonizing Theory, Practicing Solidarity. Zubaan, 2003.

Modern Ghana. "Lone Woman's Crusade.” Modern Ghana. 1 Mar. 2014. Web. 23 May 
2014. http://www.modernghana.com/news/526440/50/lone-womans-crusade.html Mordy, Jerry Tsatro. "Missing babies at KATH: Prof. Attafauh lauds government's intervention." Joy Online. 28 Feb. 2014. Web. 23 May 2015. http://www.myjoyonline.com/news/2014/February-28th/missing -babies-at-kathprof-attafauh-lauds-governments-intervention.php

Mordy, Jerry Tsatro. "KATH missing baby saga: Ministry hands case to A-G for further investigations." Joy Online. 17 June 2014. Web. 26 June 2014. http://www.myjoyonline.com/news/2014/June-17th/kath-missing-baby-sagaministry-hands-case-to-a-g-for-further-investigations.php\#sthash.Q0nShjBc.dpuf

Myjoyonline.com. “Gender ministry consoles Suwaiba.” Joy Online. 12 Mar. 2014. Web.

23 May 2014. http://www.myjoyonline.com/news/2014/March-12th/rachel-appohopoku-consoles -suwaiba.php

Myjoyonline.com, "KATH baby-missing saga: Mother battles interdicted nurses and midwives." Joy Online. 26 April 2014. Web. 26 June 2014. http://myjoyonline.com/news/2014/April-26th/kath-baby-

missing-saga-mother-battles-interdicted-nurses-and-midwives.php

Myjoyonline.com. "Suwaiba missing baby saga: Ministry issues sanctions." 12 June.

2014. Web. 9 Sep. 2014. http://www.myjoyonline.com/news/2014/June12th/suwaiba-missing-baby-saga-ministry-releases-finalsanctions.php\#sthash.eyp8qqtZ.dpuf

Naatogmah, Abdul Karim. "KATH missing baby saga: I doubt my baby is dead - Mother Cries." Citifmonline. 3 Mar. 2014. Web. 23 May 2014. http://www.citifmonline.com/2014/03/03/kath-missing -baby-saga-i-doubt-my-baby-is-dead-mother-cries/

Onyejekwe, Chineze J. "Nigeria: The Dominance of Rape." Journal of International Women's Studies 10.1 (2013): 48-63.

Owusu, Benjamin Epton. "KATH to undergo restructuring after Suweiba controversy." Citifmonline. 18 June 2014. Web. 26 June 2014. http://citifmonline.com/2014/06/18/kath-to-undergorestructuring-after-suweiba-controversy/\#sthash.iSUXv1hy.dpbs. 
Owusu-Akyaw, Richard. "PANDEMONIUM AT KATH ... Over Missing Dead Baby."

The Chronicle. 14 Feb. 2014. Web. 23 July 2014. http://thechronicle.com.gh/pandemonium-at-kath-over-missing-dead-baby/

Quaicoe-Duho, Rebecca. "MoH gives ultimatum to KATH to produce five stillborn

babies." Graphic Online. 28 Feb. 2014. Web. May 23, 2014. http://www.graphic.com.gh/news/general-news/18467

-moh-gives-ultimatum-to-kath-to-produce-five-stillborn-babies.html

Spyghana, "Suwaiba Denied Claims That Her Missing Baby Was Dead.” Spy Ghana. 8

Mar 2014. Web. 23 May 2014. http://www.spyghana.com/suwaiba-denied-claimsmissing-baby-dead/

Suwari, Alhaji. "Coalition of Ghanaian Youth for Justice for Suwaiba." Modern

Ghana. 4 Mar. 2014. Web. $20 \quad$ Feb. 2015. http://www.modernghana.com/news/526881/1/coalition-of

-ghanaian-youth-for -justice-for-suwaib.html

Schneir, Miriam. Feminism in our Time: The Essential Writings, World War II to the Present. Vintage, 1994.

Selzer, Jack. "Rhetorical analysis: Understanding how texts persuade readers." What Writing does and how it does it: An Introduction to Analyzing Texts and Textual Practices (2004): 279-307.

Sodzi-Tettey, Sodzi. "Challenges of Ghana's Health System; Akosa \& Quashigah

Diagnose!" GhanaWeb. 7 Oct. 2008. Web. 10 Mar. 2015.

Solidarities, Transnational Feminist. "Vandana Shiva and the Rhetorics of Biodiversity." Feminist Rhetorical Resilience (2012): 30.

Staudt, Kathleen, J. Monson, and M. Kalb. "Women's Political Consciousness in Africa: A Framework for Analysis." Women as Food Producers in Developing Countries (1985): 7184 
Tripp, Aili Mari, et al. "African Women's Movements." Changing Political Landscapes. New York (2009).

Tripp, Aili. "Women's Movements and Challenges to Neopatrimonial rule: Preliminary Observations from Africa." Development and Change 32.1 (2001): 33-54.

Tripp, Aili Mari. "The Politics of Autonomy and Cooptation in Africa: The Case of the Ugandan Women's Movement." The Journal of Modern African Studies 39.01 (2001): 101-128.

Tripp, Aili Mari. “Women's Movements, Customary Law, and Land Rights in Africa: The Case of Uganda." African Studies Quarterly 7.4 (2004): 1-19.

Turshen, Meredeth. "Algerian Women in the Liberation Struggle and the Civil War: from Active Participants to Passive Victims?" Social Research (2002): 889-911.

Usman, Zainab. "Celebrating the Resilience of African Women.” Nigerians Talk. 16 Mar. 2012. Web. 12 Jan. 2014. http://nigerianstalk.org/2012/03/16/celebrating-the -resilience-of-african-women/

Vinorkor, Mark-Anthony. "Parliament wades into missing baby saga at KATH." Graphic Online. 5 Mar. 2014. Web. $28 \quad$ Sept. 2014. http://www.graphic.com.gh/news/politics/18811-parliament-wades-into-missingbaby-saga-at-kath.html

Viterna, Jocelyn, and Kathleen M. Fallon. "Democratization, Women's Movements, and Gender-equitable States: A Framework for Comparison.” American Sociological Review 73.4 (2008): 668-689.

Yeboah, Isaac. "KATH missing baby must be found, dead or alive - Deputy Minister." February 22, 2014. May 23, 2014 .http://www.graphic.com.gh/news/generalnews/18133-kath-missing-baby-must-be-found-dead-or-alive-deputyminister.html\#sthash.r5YNwlfY.dpuf 


\section{Appendix A}

\section{Full recommendations by the MoH after investigations on the missing babies}

The Ministry of Health would like to announce to the general public that it has received the final report from the three (3) institutions who were asked to investigate the unfortunate incident that happened a few months ago at the Komfo Anokye Teaching Hospital (KATH) in Kumasi.

The institutions were; the Nursing and Midwifery Council, Medical and Dental Council and the Komfo Anokye Teaching Hospital.

It will be recalled that a 42 year old mother, Suwaiba Mumuni, who was carrying her second term pregnancy, was referred to the Komfo Anokye Teaching Hospital from Amaamata Memorial Maternity Clinic in Kumasi for further treatment.

She was admitted eventually had a still birth but hours later she requested for the still born baby for burial or otherwise but the KATH authorities would not produce the still born baby.

During that trying moment, the Ministry of Health assured the general public; especially the families of the mother and other mothers who lost their babies that, it will not rest on its effort of carrying out an investigation into the allegation. We also assured the families that, we would be seeking justice in the matter.

The Ministry has accepted the recommendation from the Medical and Dental

Council, Nursing and Midwifery Council and the Komfo Anokye Teaching Hospital Management as follows:

\section{CONDUCT OF THE MIDWIFE ON DUTY WHO ATTENDED TO MADAM SUWAIBA MUMUNI AT THE KOMFO ANOKYE TEACHING HOSPITAL,}

FROM 4TH - 5TH FEBRUARY, 2014

No professional negligence or misconduct was found against Ms. Sophia Addai by the professional regulatory council. However, it is recommended that her final exoneration should await completion of the forensic investigation by the police. The Council however, found professional negligence on the part of Ms. Patience Amposah (Midwife who was head of the night shift on the 4th and 5th February, 2014) and Ms. Marian Asare (Midwife in charge of A1 labour ward). 
Ms. Patience Amposah failed to hand over the three still born babies in the utility room at the end of her shift physically to Ms. Asare who in turn failed to ascertain the presence or other wise of the still born babies before taking over.

\section{SANCTIONS RECOMMENDED BY THE REGULATORY COUNCIL}

- Ms. Marian Asare, Principal Midwifery Officer, the Midwife in charge of the labour ward should be suspended from midwifery practice for four (4) weeks without pay.

- Ms. Patience Amposah, Senior Staff Midwife and the Midwife who was the head of the night shift on the A1 labour ward should be suspended from the practice of midwifery for two (2) weeks without pay.

It is worth noting that the two Midwives would have to undergo an orientation programme prescribed by the council and submit evidence in this regard before their licenses will be restored.

3. SANCTIONS RECOMMENDED BY THE ENQUIRY COMMITTEE FOR THE ORDERLY

The Orderly, Baba should continue to be on leave until the police complete their investigation into the case.

\section{KOMFO ANOKYE TEACHING HOSPITAL (KATH) MANAGEMENT}

- The management of the hospital should establish well defined channels of communication between the hospital and the media/bereaved families;

- The orderlies and other hospital staff should be excluded from private arrangements for the burial of still born babies;

- All stillbirths should be certified and death certificates issued;

- There should be fluid communication between Doctors and Midwives in attending to patients and prompt discussion of adverse findings to facilitate best practices;

- Security should be beefed up at the maternity unit of the hospital;

- The DDNS in charge of Obstetrics/Gynaenacology Department must intensify her supervisory duties and ensure the provision of adequate logistics and staff for the labour ward;

- The Management of the hospital should organize customer care training for all cadres of the hospital staff;

- The hospital management should device ingenious ways to collaborate with referring hospitals to decongest the maternity unit, while efforts are being made to solicit funds to complete the maternity and children's block at the KATH;

\section{MADAM SUWAIBA MUMINI}

That Madam Suwaiba and family should be provided emotional support through the services of a Clinical Psychologist; 
- That she should be offered further assistance for her infertility treatment if necessary

\section{MINISTRY OF HEALTH}

- The Ministry of Health will develop Standard Operation Procedure (SOP) manuals for maternal and child health including neonatal care and ensure compliance;

- Specifically, Standard Operation Procedure should be developed for the following:

a. Labour, Deliveries and Discharges

b. Management of still births and neonatal deaths

c. Bereavement and Burial of dead babies

d. Protocol on baby theft

e. Development of protocols and guidelines for clinical audit

f. Redesign still births and mortuary registers to capture more vital information for better identification

- The Ministry will strengthen supportive supervision, monitoring and evaluation of clinical practices;

- The Ministry will institute awards to motive hard working institutions and apply sanctions where necessary;

\section{GENERAL RECOMMENDATIONS FOR ALL HEALTH SERVICE INSTITUTIONS}

- Management of all hospitals should set up committees to review existing systems to improve performance;

- Management should ban all hawkers from clinical areas including wards;

- Records on each patient from both Doctors and Midwives should be Records on each patient from both Doctors and Midwives should be contained in the same folder. These on the labour ward should be part and parcel of the partograph for monitoring the laboring woman;

- The still births and mortuary registers should be redesigned to capture more vital information for better identification;

- All support staff within the lower cadre employed by hospitals such as orderly and mortuary attendants must have acquired basic education. They must be able to read and write;

- There should be effective and efficient communication between the midwives and the doctors with doctors having oversight responsibility on their activities.

- Job description should be clearly spelt out and new staff supervised in the initial stages to ensure adherence to standard operation procedures;

- The use of ultrasound scans to clarity uncertainties if intrauterine fetal death is suspected; 
- Whenever a still birth occurs, the mother before discharge should inform the hospital authorities on the family's decision about burial or disposal of the body;

- Creating awareness and regular training of staff on protocols and guidelines will create the necessary awareness to minimize the deficiencies that led to substandard care and patient dissatisfaction;

- Continuing professional development (CPD) programmes should organized periodically for all cadres of health workers based on local needs assessment;

- The hospitals should incentivize hard working staff.

\section{MEDICAL AND DENTAL COUNCIL ${ }^{1}$}

The investigation of the Medical and Dental Council cleared Dr. Michael Adow of negligence or professional misconduct on his part in the case of Madam Suwaiba.

The Ministry therefore request that Management of Komfo Anokye Teaching hospital should recall him from Leave.

Additionally, the Minister will ensure that every health facility delivers quality health care to the people of this country. The Ministry will also intensify its effort to improve attitudes and behavoural change of health personnel, any health worker found culpable or going contrary to its mission, aim and objectives will face full rigors of the laws.

The Ministry wishes to commend the media for its reportage of the issue and other issues in the health sector in its quest to promote quality health care. Thank you.

Myjoyonline.com. "Suwaiba missing baby saga: Ministry issues sanctions." 12 June.

2014. Web. 9 Sep. 2014. http://www.myjoyonline.com/news/2014/June12th/suwaiba-missing-baby-saga-ministry-releases-finalsanctions.php\#sthash.eyp8qqtZ.dpuf

Isaac. Permission to Use Copyrighted Material Ruby Pappoe. 7 May 2015. Phone.

(Since Joy Online is a public news website, any material that it publishes on the website falls within the public domain, thus I do not need permission to use this material). 


\section{Appendix B}
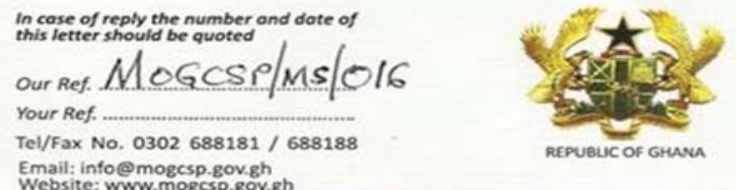

MINISTRY OF GENDER, CHILDREN AND SOCIAL PROTECTION

P. O. BOX MBO 186 MINISTRIES - ACCRA Date $7 / 03 / 14$

\section{RE: PETITION BY THE GHANAIAN SOCIETY TO THE INSTITUTIONS OF STATE DEMANDING JUSTICE AND ACCOUNTABILITY FOR SUWAIBA AND THE FOUR OTHER WOMEN WHOSE BABIES WENT MISSING AT KOMFO ANOKYE TEACHING HOSPITAL, ("KATH")}

I acknowledge receipt of your letter dated $10^{\text {th }}$ March, 2014 petitioning the Hon. Minister about the incidence involving the 'missing' babies at the Komfo Anokye Teaching Hospital.

2. This Ministry has noted the concerns and issues raised in the Petition and is giving due consideration to same. We will provide you with our response in due course.

3. Thank you for your concern.

THE PETITIONERS

IN THE MATTER OF SUWAIBA AND THE FOUR WOMEN

WHOSE BABIES WENT MISSING AT KOMFO ANOKYE

TEACHING HOSPITAL, ("KATH")

Fig. 3. A letter posted on the Facebook page, showing participants the Ministry's

response to the petition they sent regarding the missing babies. ; KATH, Where is the baby?" Facebook. Facebook, 7 June 2014. Web. 26 Sept. 2014. 